\title{
A gravitational spreading origin for the Socompa debris avalanche
}

\author{
B. van Wyk de Vries ${ }^{\mathrm{a}, *}$, S. Self ${ }^{\dagger, 1}$, P.W. Francis ${ }^{\mathrm{c}, 2}$, L. Keszthelyi $^{\mathrm{d}}$ \\ ${ }^{a}$ Magmas et Volcans (UMR 6524), Observatoire du Physique du Globe, Université Blaise Pascal, 5 rue Kessler, 63038 Clermont-Ferrand, \\ France \\ ${ }^{\mathrm{b}}$ SOEST, University of Hawai'i, 2525 Correa Road, Honolulu, HI 96822 USA \\ ${ }^{\mathrm{c}}$ Department of Earth Sciences, The Open University, Walton Hall, Milton Keynes, MK7 6AA, UK \\ ${ }^{\mathrm{d}}$ Planetary Image Research Laboratory, Lunar and Planetary Laboratory, University of Arizona, Tucson, AZ 85721, USA
}

Received 21 January 2000; accepted 29 July 2000

\begin{abstract}
Socompa Volcano arguably provides the world's best-exposed example of a sector collapse-derived debris avalanche deposit. New observations lead us to re-interpret the origin of the sector collapse. We show that it was triggered by failure of active thrust-anticlines in sediments and ignimbrites underlying the volcano. The thrust-anticlines were a result of gravitational spreading of substrata under the volcano load. About $80 \%$ of the resulting avalanche deposit is composed of substrata formerly residing under the volcano and in the anticlines. The collapse scar can be traced up to $5 \mathrm{~km}$ from the edifice, truncating two spreading-related anticlines, which collapsed in the event. Outcrops near the volcano preserve evidence of edifice material being carried along on top of mobilised substrata. On the north side of the scar, the avalanche motion was initially at right angles to the failure edge. Structural relations indicate that immediately prior to collapse the substrata disintegrated, became effectively liquidised, and were ejected from beneath the edifice. Catastrophic mobilisation of substrata probably resulted from breakdown of ignimbrite clasts and cement. It may have occurred through progressive rock fracture by high shear strain during spreading. Material ejected from under Socompa formed a layer on which volcanic edifice debris was transported. This interpretation of events explains the puzzling observation that avalanche units with the lowest gravitational potential energy moved the furthest. It can also account for avalanche motion normal to the collapse scar walls. Ignimbrites and other rock types probably capable of similar behaviour underlie many other volcanoes. Identification of spreading at other sites could therefore be a first step towards assessment of the potential for this style of catastrophic sector collapse. (C) 2001 Elsevier Science B.V. All rights reserved.
\end{abstract}

Keywords: Socompa; sector; collapse; spreading; debris; avalanche

* Corresponding author. Tel: +33-04-73-346732; fax: +33-0473-346744.

E-mail addresses: vanwyk@opgc.univ-bpclermont.fr (B. van Wyk de Vries), self@lani.soest.hawaii.edu (S. Self),

lpk@jupiter.lpl.arizona.edu (L. Keszthelyi).

${ }_{1}$ Tel.: +1-808-956-5996; fax: +1-808-956-2538.

$\dagger$ P.W. Francis died on 30 October 1999.

\section{Introduction}

\subsection{Description of Socompa volcano and its avalanche}

Socompa Volcano (Fig. 1) has one of the most voluminous terrestrial sector collapses and avalanche deposits and is remarkably well preserved by the hyper-arid climate of the Atacama Desert of northern Chile (Fig. 2). The deposit's freshness provides an 


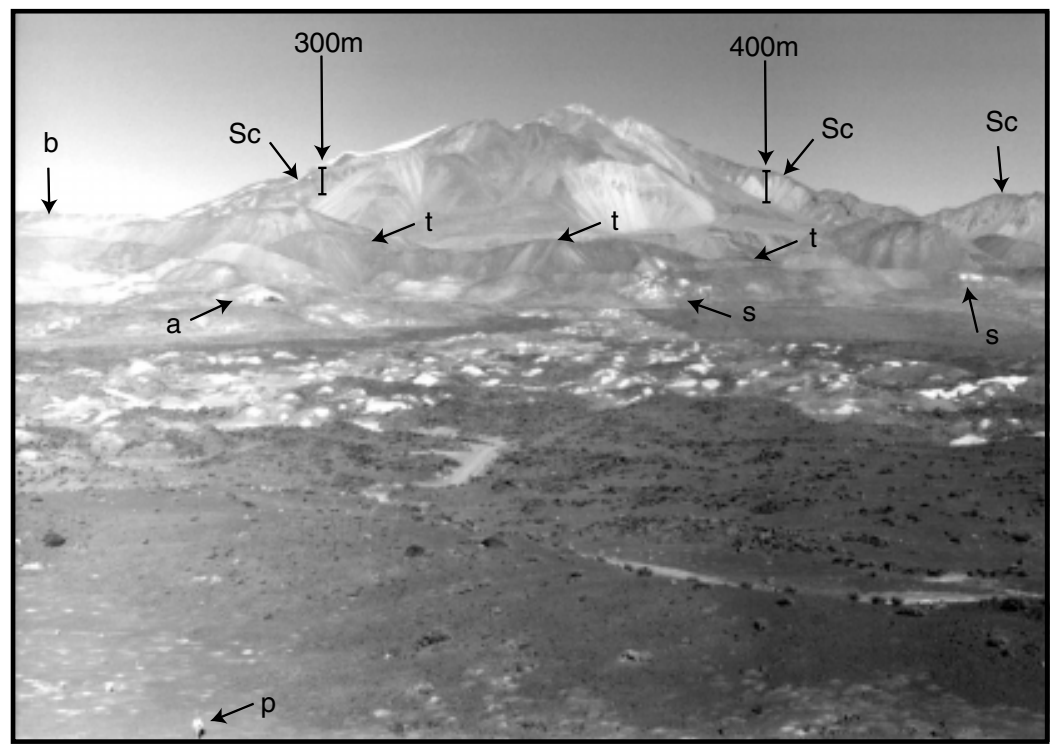

Fig. 1. View of Socompa volcano from west (point X in Fig. 4), standing on the secondary scarp and looking directly at the scar. The left side of the scar $(\mathrm{Sc})$ is outlined by white pumice. A scale bar is provide on either side of the scar. In the centre of the scar post-collapse lavas mantle "Domo del Nucleo", a light coloured area of original cone. Below this are toreva blocks (t). Viewer is looking up a light coloured debris flow lineation, composed of substratum material, with a thin veneer of Socompa debris. Fault scarps dipping toward viewer expose lower cushion of substratum material, which we call reconstituted ignimbrite facies (RIF). A dark point, covered by RIF, on the mid-left is an outlying Negrillar lava flow (point a). Point s indicates substrata outcrop at base of toreva blocks, and b Lomas de Pajonales ridge. p indicates figure of Steve Self at base of secondary scarp. There is about $3000 \mathrm{~m}$ of elevation difference between summit and view point, and the scar mouth is about $12 \mathrm{~km}$ wide.

excellent opportunity to study the causes and consequences of large-scale sector collapse. The collapse scar is a wedge, $12 \mathrm{~km}$-wide at its mouth and $\sim 300 \mathrm{~m}$ deep (Fig. 3). The avalanche deposit has a volume of $36 \mathrm{~km}^{3}$, of which $11 \mathrm{~km}^{3}$ are toreva (Reiche, 1937) blocks (volumes from Wadge et al., 1995), standing in the mouth of the collapse scar. The majority of the avalanche deposit is made up of ignimbrites and gravels that were laid down before Socompa was formed. The remaining volume is composed of a veneer of volcanic rocks from Socompa and some lacustrine and evaporite salar deposits (Ramirez, 1988; Wadge et al., 1995). The Socompa avalanche deposit covers almost $500 \mathrm{~km}^{2}$. The excellent preservation allows the full complexity of the deposit to be examined. Field studies have been greatly aided by the recent increase in road accessibility.

Initially, the Socompa avalanche deposits were interpreted as the product of a large eruption and pyroclastic flow due to the high proportion of pumiceous material present (Deruelle, 1978). Subsequently, the feature was recognised as a sector collapse and debris avalanche deposit (Francis et al., 1985). Initial interpretations of the collapse assumed that it was the result of a Mt. St. Helens-style lateral blast (Ramirez, 1988). However, the recognition that a large portion of the avalanche material is from below the volcano (Deruelle's pumiceous material), and the observation of sharp topographic changes near the volcano, shifted the emphasis from explosive failure to gravitational collapse. The suggestion that the avalanche was due to failure over a normal fault (Francis and Self, 1985) was followed up by Wadge et al. (1995), who concluded that failure in the sub-volcanic sloping strata caused the collapse.

We have combined new field studies with recent ideas about the relationship between gravitational spreading and sector collapse (van Wyk de Vries and Francis, 1997) to reinterpret the formation of the Socompa avalanche. Due to the overwhelming abundance of pre-Socompa volcano material in the avalanche deposit, we now consider the role of the 


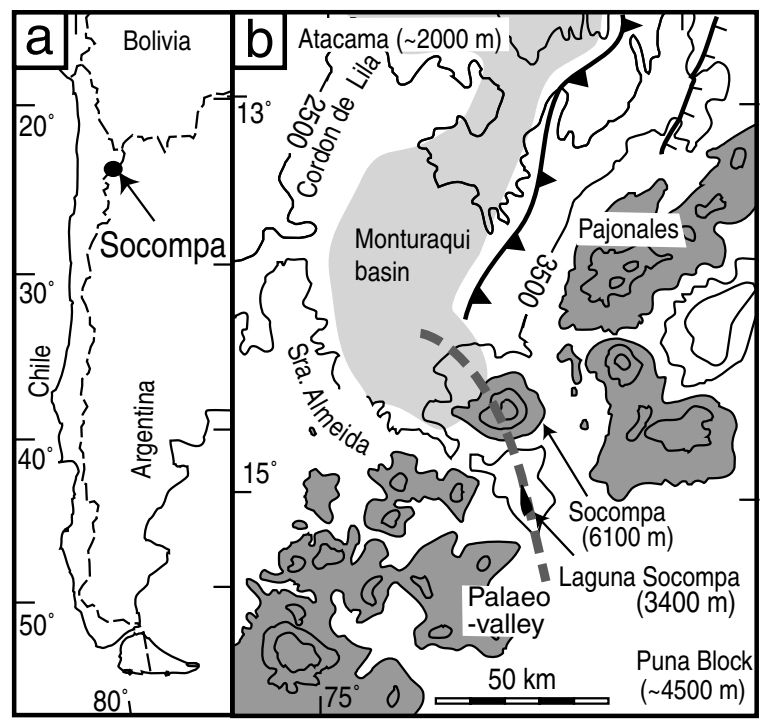

Fig. 2. Location of Socompa. (a) location of Socompa in South America; (b) Major topographic, geographic and structural features around Socompa. Over $4000 \mathrm{~m}$ the relief is darkly shaded and contours are every $1000 \mathrm{~m}$. The extent of the Monturaqui Basin is indicated by light shading. Thrust and normal faults shown are part of the Socompa-Chiliques spreading system described by van Wyk de Vries and Borgia (1996). Dotted line through Socompa indicates approximate trace of broad valley probably existing prior to the volcano.

underlying material to be dominant in the interaction between volcano and basement, as opposed to volcanic activity being the primary cause for the collapse. We present new field observations suggesting a model where extrusion of the strata from beneath the volcano generated thrusts and anticlines, which created the conditions necessary for sector collapse to occur. We also present additional field observations that lead us to conclude that the Socompa avalanche occurred by catastrophic ejection of liquidised materials from beneath the volcanic edifice.

\section{Data presentation}

\subsection{Geological setting}

Socompa Volcano lies at the south-eastern end of the Atacama Basin, where the Puna Block meets Cordon de Lila and Sierra Almeida (Figs. 2 and 3). Although there are large topographic features in the vicinity of Socompa, there are no recognised regionalscale tectonic structures, such as faults (Reutter et al., 1994). The west and northwest flanks of the volcano face the broad Monturaqui Valley, which lies at about $3200 \mathrm{~m}$ a.s.l. The southeast flanks slope down to a basin around $3400 \mathrm{~m}$ a.s.l, containing the Laguna Socompa (Fig. 2). The other flanks slope down to other volcanoes of the western volcanic chain, such as Cerro Pajonales (5950 m), Salin (6000 m), Cerro
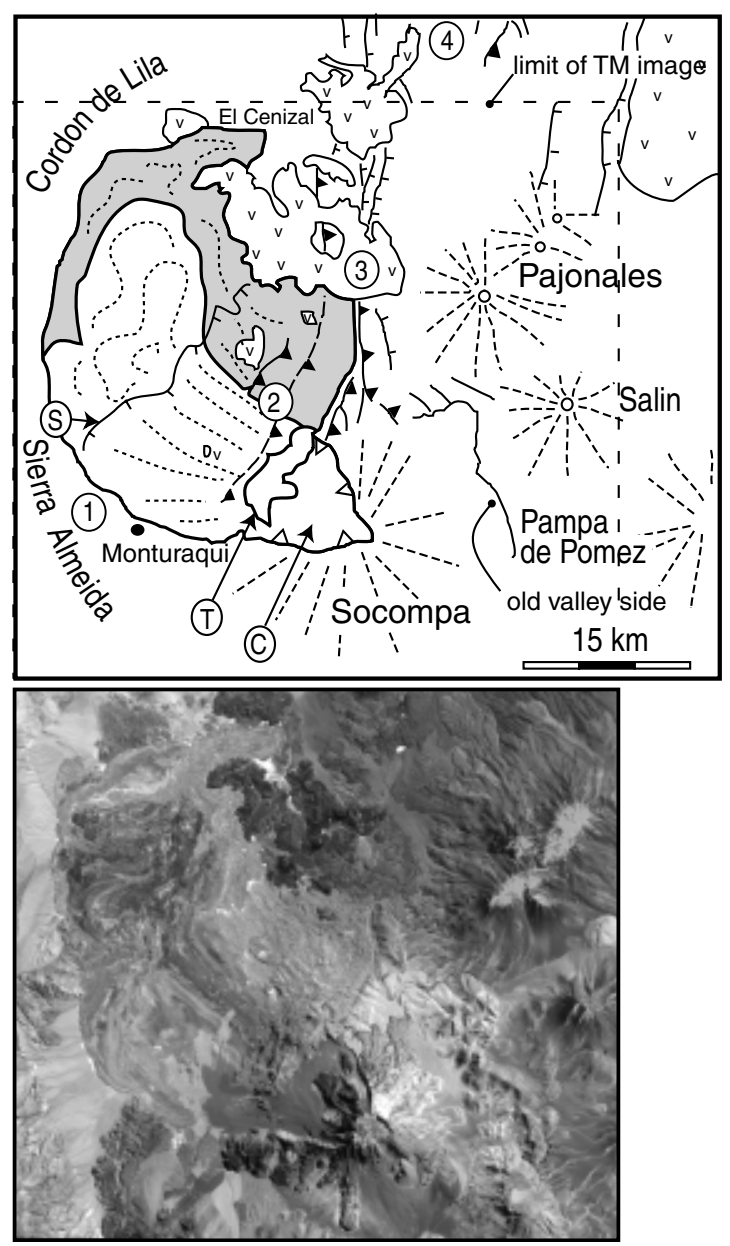

Fig. 3. Map and Landsat TM image of Socompa, showing local structural and topographic features and major components of debris avalanche. Encircled letters denote: C, Collapse scar; T, toreva blocks; S, secondary scarp. Orientation of debris streams on either side of secondary scarp are shown by the dotted lines. The Monturaqui unit of avalanche (Wadge et al., 1995) is white, while El Cenizal unit is shaded. Lavas of the Negrillar field are indicated by $\mathrm{v}$. Encircled numbers indicate deformation areas discussed in the text (Section 5.5). 
Bayo $(5340 \mathrm{~m})$ and Socompa Cairis $(5200 \mathrm{~m})$. These volcanoes show evidence of glaciation, in contrast to Socompa, where volcanic features are very fresh and where there has been little erosion. This apparently constrains the age of the latest activity at Socompa to $<10,000$ years (when the last glaciation occurred). A thin pyroclastic surge deposit at Monturaqui is dated at about 7000 years BP (Ramirez, 1988). The Socompa edifice occupies what was once a broad valley, draining from Laguna Socompa to the Monturaqui Basin (Fig. 2).

The basement below Socompa Volcano is composed of Lower Palaeozoic granitic and metamorphic rock, overlain by folded strata comprising Devonian quartzites, Permian acidic volcanic rocks and Upper Cretaceous clays and sands of the Purilactus Formation (Reutter et al., 1994). Above the basement, in the Monturaqui Basin (Fig. 2), there is a $500 \mathrm{~m}$ thick layer of Miocene-Oligocene clays and conglomerates of the San Pedro and Tambores Formations. The Pliocene-Miocene Salin Formation forms a $\sim 200 \mathrm{~m}$ thick layer below the volcano, capped only by Socompa-derived volcanoclastic layers (Ramirez, 1988).

The Salin Formation is composed of gravels and conglomerates, with intercalated ignimbrites such as the Tucúcaro (3.2 Ma K/Ar date) and the Arenosa ignimbrites (2.5 Ma K/Ar date), (Ramirez, 1988). The Salin Formation gravels and conglomerates are poorly consolidated to unconsolidated, are mainly matrix supported and contain sand-rich layers up to $10 \mathrm{~m}$ thick and hundreds of meters long. The clasts are mostly volcanic, and in the upper layers at La Flexura locality (Fig. 4) they are petrographically similar to Socompa lavas. The Tucúcaro ignimbrite is slightly welded and about $5 \mathrm{~m}$ thick, while the Arenosa ignimbrite is pumice-rich, unwelded but lithified, with columnar joints, and is about $30 \mathrm{~m}$ thick. Other, thinner pyroclastic flow units within the Salin are lithicrich with large pumice clasts (up to $10 \mathrm{~cm}$ ) and an ash matrix. Drilling logs indicate that the thickness of the Salin Formation varies from $\sim 200 \mathrm{~m}$ below the avalanche deposit to $300 \mathrm{~m}$ on the east side of the volcano (Ramirez 1988). The petrologic similarity between some clasts in the upper part of the Salin and Socompa lavas leads us to suggest that the latter part of the Salin Formation and the early Socompa Volcano were coeval. The Salin Formation also includes small lenses of lacustrine and evaporite units that are also found in many small basins around Socompa.

The Monturaqui Basin is the major water source for mines in the region, and the water table at present lies at $100-200 \mathrm{~m}$ below ground level (Steve Foot, pers. commun.). The level of Laguna Socompa at $\sim 3400 \mathrm{~m}$ gives an indication of the water table height $50 \mathrm{~km}$ to the southeast and suggests a small regional hydraulic gradient. As the Salin rocks are highly permeable, the water table probably does not rise significantly under the volcano, and may remain at the same stratigraphic level. Water is likely to have been more abundant at the time of collapse (just after the last glaciation) but there is no evidence of other than ephemeral surface water flow on the volcano or avalanche deposit.

From a structural viewpoint, the main divisions of this stratigraphy are: (1) the pre-Tertiary basement composed of crystalline metamorphic and igneous

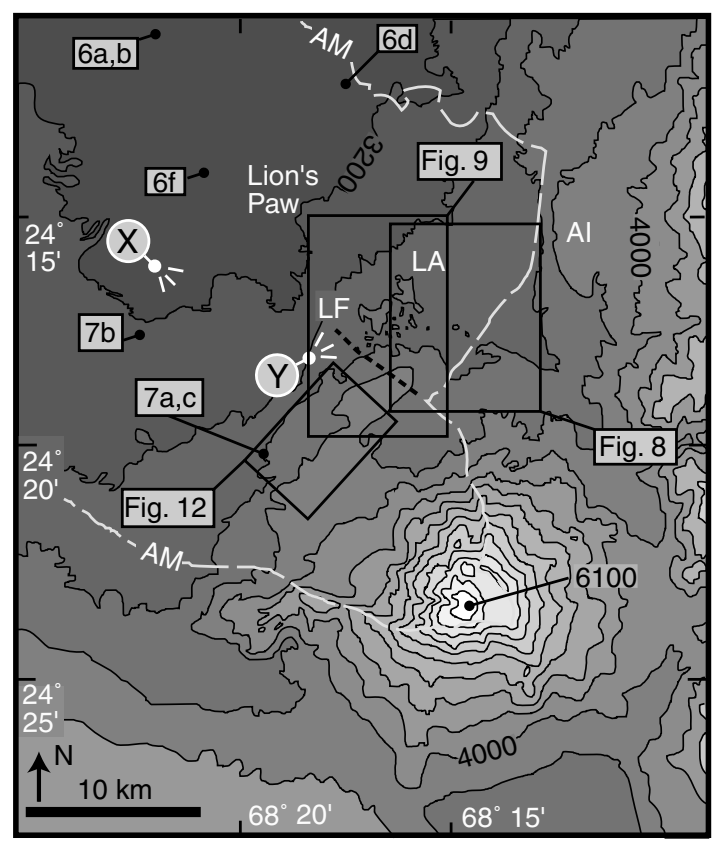

Fig. 4. Shaded topographic map of Socompa, with contours every $200 \mathrm{~m}$ and with the outline of collapse scar and deposit shown with light dashed line. The locations of areas shown in Figs. 8, 9 and 12 are indicated. Outcrop locations for Figs. 6 and 7 are also shown. The viewpoints for the photographs in Fig. 1 (X) and Fig. 10 (Y) are given. AM, avalanche margin; LF, La Flexura; LA, Loma Alta; AI; Altos de Inca. 


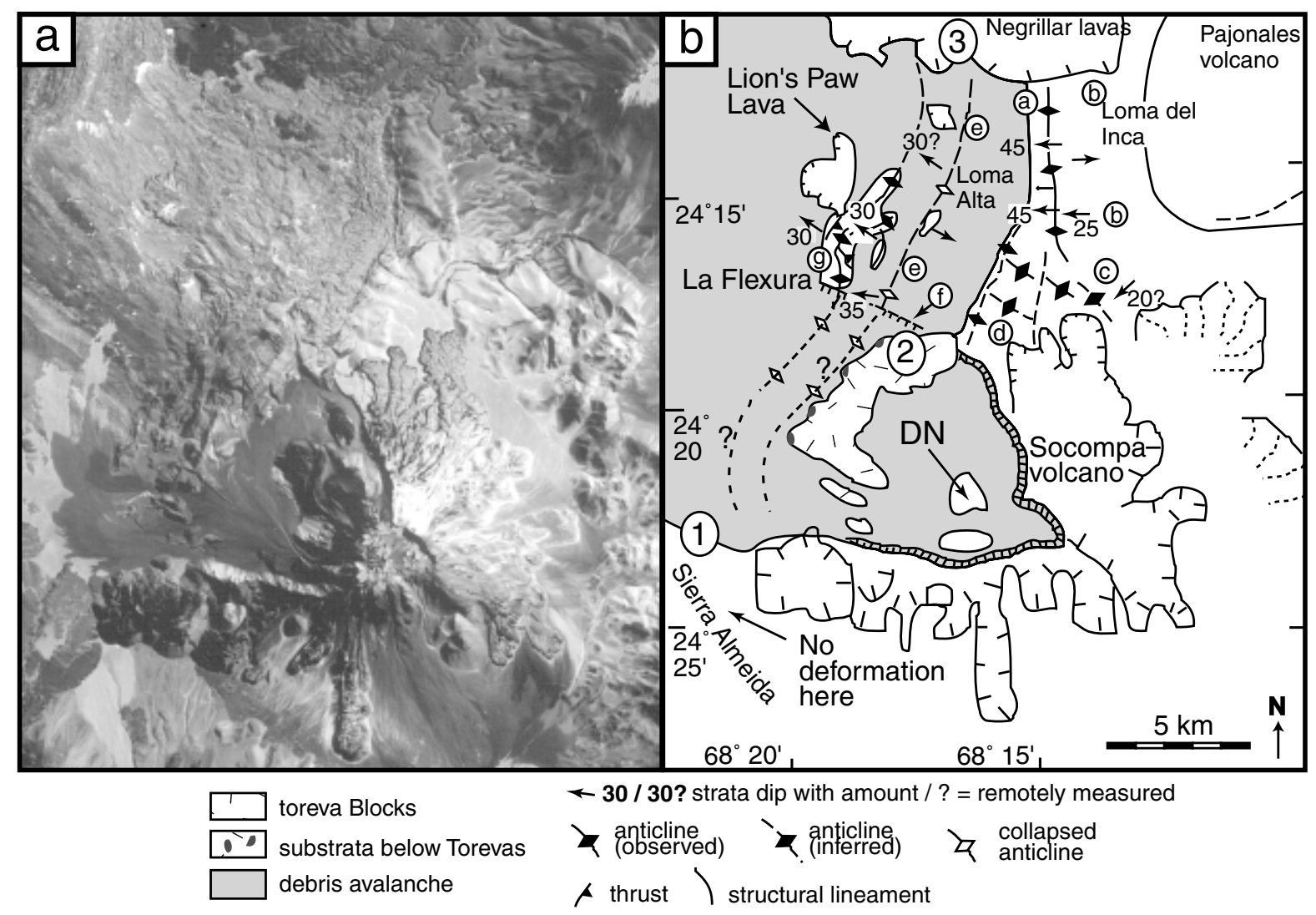

Fig. 5. Main structural features mapped at Socompa, including Loma del Inca-La Flexura deformation belt and collapse scar morphology. (a) Landsat TM image of map area; and (b) structural map. Circled letters indicate points described in text. Circled numbers refer to distinct deformation areas referred to in discussion. Dip of strata with dip value were field measured, while those without value are from remote observations. DN, Domo del Nucleo.

rocks; and (2) about $700 \mathrm{~m}$ thickness of TertiaryQuaternary sedimentary and pyroclastic materials. The crystalline rocks are unlikely to have deformed significantly, but the largely unconsolidated Tertiary sequence and Oligocene-Miocene clays are not likely to be able to support the Socompa edifice load (van Wyk de Vries and Borgia, 1996).

\subsection{Description of collapse scar morphology}

The collapse scar is a wide wedge facing westnorthwest (Figs. 3 and 4). Its walls are $200-400 \mathrm{~m}$ high (Fig. 1). The wedge is shallow relative to its width, with slightly convex contours (Fig. 4). Isolated outcrops of original cone material, such as the Domo de Nucleo, are found within it (Fig. 5) (Ramirez, 1988). A deep, curved scar shape has been previously postulated for Socompa (e.g. Wadge et al., 1995). However, the common basal profile of a wedgeshaped collapse scar is shallow, such as those found at Mombacho, Raung, Bandai San, or Iriga (van Wyk de Vries and Francis, 1997; van Bemmelen, 1970; Siebert, 1984). Although the scar is partially covered by post-collapse lavas and pyroclastics, there are outcrops of the pre-avalanche Socompa rock. These have been interpreted as being slump blocks (Ramirez, 1988; Wadge et al., 1995), but they may also be inliers of intact rock beneath a shallow avalanche slip plane. The mouth of the wedge is choked with toreva blocks, except at the extreme 
south. Small outcrops of Salin ignimbrite are found at the base of the toreva blocks.

The southern wall of the collapse is clearly exposed as a straight, steep scarp extending down to the foot of the volcano, where it is covered by avalanche and later pyroclastic flow material. There is no evidence here to suggest that the scar extended beyond the foot of the volcano. The centre of the scar is composed of a crater-like embayment and the northern scar wall makes a sharp junction with this, descending in a straight line northwest (Figs. 4 and 5). The lower part of this wall is covered by toreva blocks, which moved northwards over the margin. In line with the scar wall, blocks are cut by many southeasterly trending faults. Below the toreva blocks these faults continue through substrata rocks comprising Loma Alta and La Flexura ridges (Fig. 5). They terminate at La Flexura cliff, where a depth of $>150 \mathrm{~m}$ of material has been removed (see Section 3.3). This indicates a continuation of the avalanche scar away from the volcano foot, with La Flexura being the lowermost expression of the scar, $5 \mathrm{~km}$ from the volcano (Figs. 4 and 5).

We estimate the volume of material that was in the wedge using:

(a) the scar wall height of 300-400 m (allowing for some infill from post-collapse material);

(b) a pre-collapse outcrop in the scar, which defines portions of the wedge floor;

(c) an assumption that the edifice was roughly conical with a curved surface defined by the shape still existing outside the scar. The total wedge volume by this calculation is between 6 and $7 \mathrm{~km}^{3}$. This is about a third of that calculated by Wadge et al. (1995) for a deep, circular decollement. It is also less than the volume of the toreva blocks (Wadge et al., 1995).

\subsection{Description of the avalanche deposit}

The avalanche deposit extends up to $40 \mathrm{~km}$ away from the volcano, filling the Monturaqui Basin and spreading up slopes of the Sierra Alamedia and Loma del Inca (Fig. 3). The most distal tongue of debris moved northeastwards, breached the Negrillar lavas and extended to El Cenizal valley (Ramirez, 1988; Wadge et al., 1995). The avalanche deposit can be separated into several units by its surface composition; the two main units are the Monturaqui (dominated by a surface of Socompa material) and El Cenizal (dominated by Salin Formation rock) (Wadge et al., 1995). The deposit can be further separated into a lineated proximal region (dominated by parallel stripes of debris aligned along the transport direction, crossed by parallel, curved structural ridges) and a distal convolute region. These two regions are separated by a ridge (the 'secondary scarp' of Ramirez, 1988) where a component of flow against the main transport direction is indicated (Fig. 3, feature S).

Some of the debris streams contain prismatically jointed dacite blocks up to $10 \mathrm{~m}$ across. In addition, there is a welded pumice layer covering many of the higher toreva blocks, and a pumice deposit covering the north side of the volcano. These features indicate that active magma and/or lava were present in the volcano at collapse. Wadge et al. (1995) report a thin surge deposit near Monturaqui, which may have accompanied the collapse and which provided a $\mathrm{C}^{14}$ date of $7200 \mathrm{BP}$. We found, however, no other evidence of a lateral blast, a feature likely to have been preserved on areas such as the Negrillar lava field.

\subsection{Description of avalanche units}

Using remote sensing data, Wadge et al. (1995) found that $35 \%$ of the surface consisted of preSocompa rocks, and speculated that the actual volumetric proportion of substrata was much higher. In 1996, using the many roads cut through the avalanche during water exploration by the Escondida and Zaldivar mines in 1992-1994, we were able to make a revised estimate.

At each outcrop, we divided the avalanche into three main types of breccia (Fig. 6):

(1) Reconstituted ignimbrite facies (RIF). This is dominantly $(>90 \%)$ fine Salin Formation ignimbrite material, gravels and sands. There are also sparse clasts of Socompa-like lava and a few blocks of salar sediments (Fig. 6a and b).

(2) Socompa breccia (SB). This is composed of fractured clasts of Socompa lava and tephra up to megablock size $(10 \mathrm{~m})$ in a powdery matrix (Figs. 6c, f and 7b).

(3) Mixed RIF and SB (RIFSB). This is a combination of the RIF and $\mathrm{SB}$, in various degrees of mixing 
from RIF containing intimate stringers of SB to a complete mixture of the two (Fig. 6d).

Locally, salar lacustrine and evaporitic sediments, including diatomaceous deposits, are major components. Such materials are most common on the west side of the most distal lobe, where large amounts are found bulldozed against the avalanche margin in thrusts and folds, or mixed with RIF facies.

\subsubsection{The main avalanche units}

El Cenizal and a part of the Monturaqui unit, Mo1 (Wadge et al., 1995, Fig. 7) are composed of RIF with
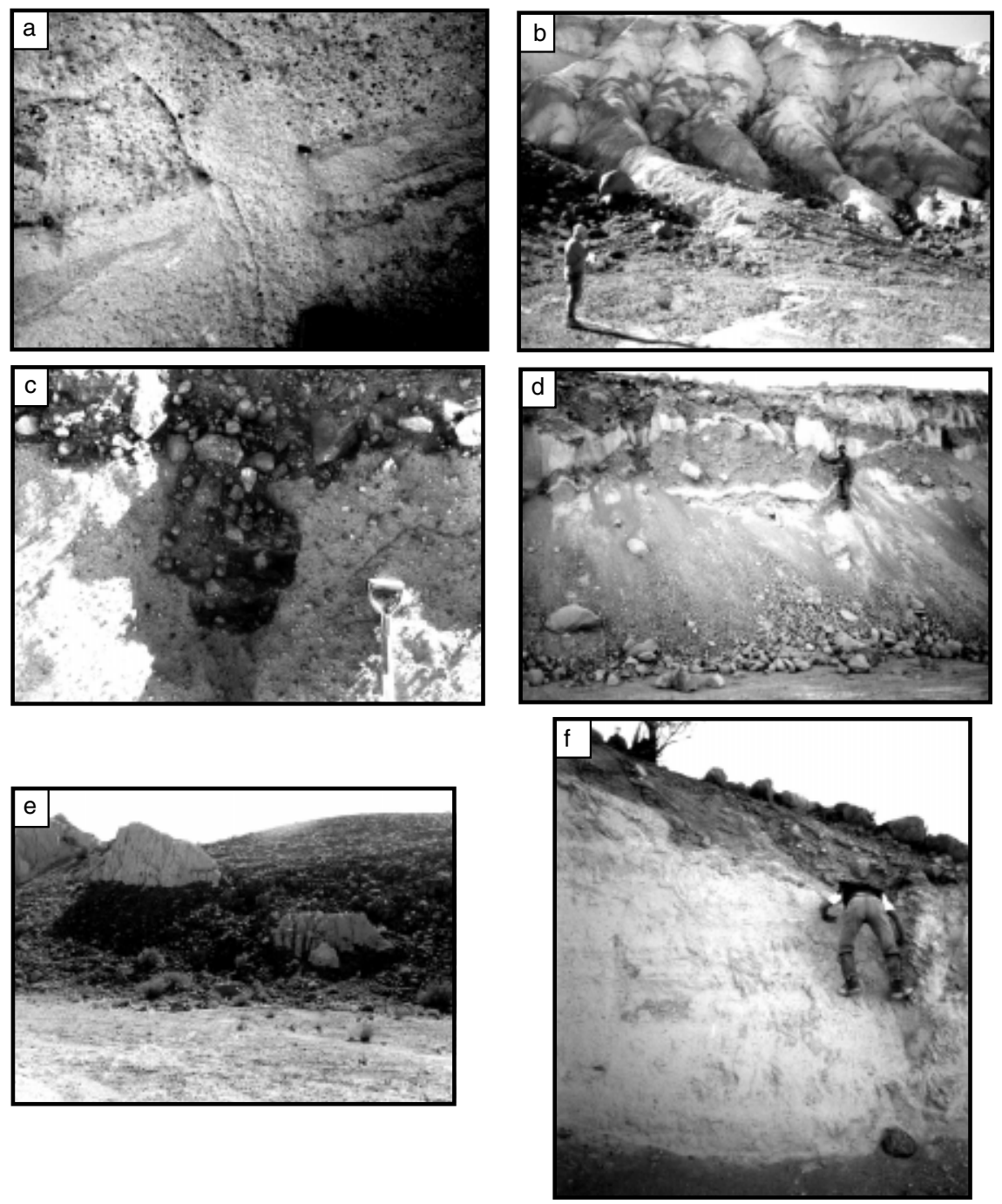

Fig. 6. Compositional, structural and rheological features of Socompa debris avalanche deposit as seen in field (locations shown in Fig. 4). (a) RIF seen closely at outcrop scale (width of photograph $=1 \mathrm{~m}$ ), showing a diapir piercing flow banding. Note lack of pumice clasts compared with intact ignimbrite in Fig. 9a. (b) Banding in RIF, at same locality as e, with stringers of RIFSB and a very thin top layer of SB. Person for scale. (c) Inverted diapir structure between RIF and SB in distal end of the avalanche, with spade handle for scale. (d) Banding of RIF and RIFSB at the margin of El Cenizal unit. It is unclear here how much of RIFSB is original Socompa rock or Salin gravels. Person for scale. (e) Eroded remnants of reconstituted ignimbrite facies (RIF) covering on side of a Negrillar lava, next to the terminal lobe. The RIF tower to lower right of slope is about $4 \mathrm{~m}$ high. (f) Thin veneer of SB over RIF in El Cenizal unit, with person for scale. 

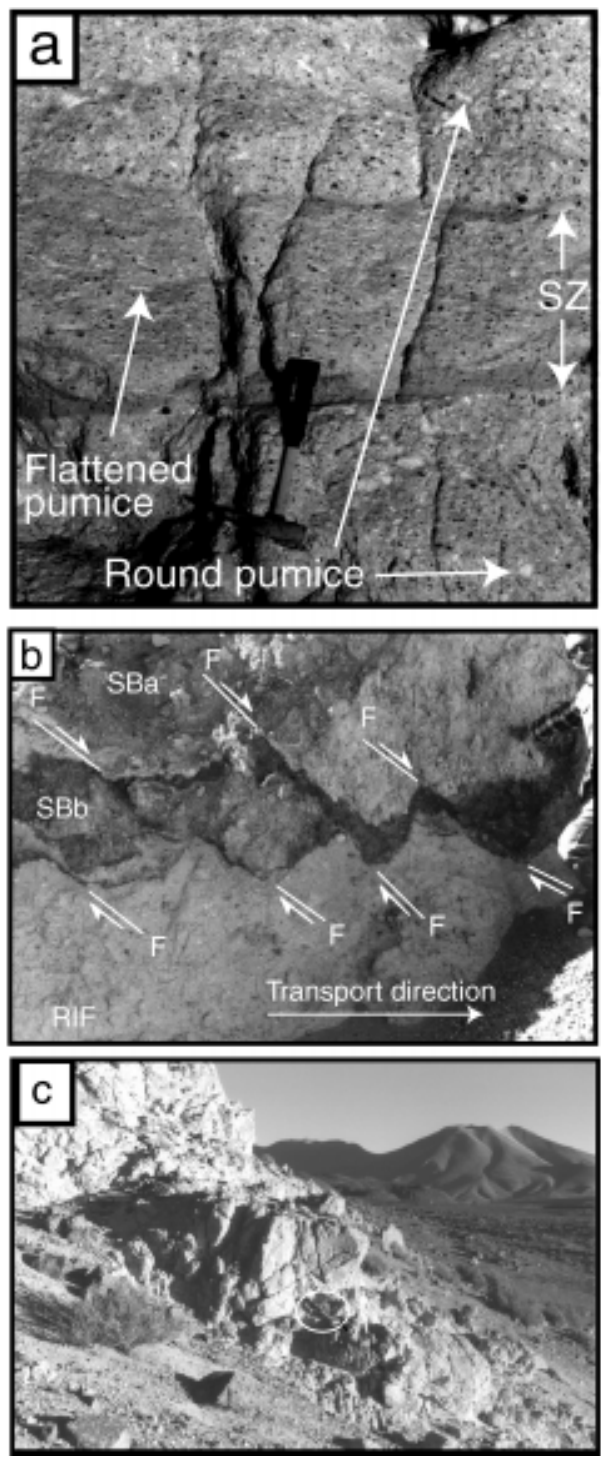

Fig. 7. Deformation features in Salin substrata and avalanche deposit. For location see Fig. 4. (a) Photo of sheared Salin ignimbrite under a toreva block. A shear zone about $30 \mathrm{~cm}$ across is shown by SZ. On either side of this, pumice clasts are rounded, but they become progressively more flattened towards shear zone. There are two bands of finegrained material, which bound the shear zone. They are discontinuous and composed of aligned fragments of pumice. We interpret these as shear zone gouge. Hammer for scale. (b) Photo of shear rotation on a cutting through debris avalanche (see Fig. 4 for location). Person for scale. (c) View of fractured Arenosa ignimbrite at base of a toreva block. There is a hammer for scale in the ellipse. The fractures are linear, apparently randomly orientated. Block above hammer is surrounded by a densely fractured ignimbrite. Compare these fractures with the massive ignimbrite in (a). See Fig. 4 for location. a thin overlying layer $(0.5-2 \mathrm{~m})$ of light coloured SB. The other Monturaqui units also have an upper layer of SB, the thickness of which is greater (2 to $>15 \mathrm{~m}$ ), and some RIFSB is found below. The whole deposit is, therefore, based on a thick RIF cushion, with a veneer of Socompa-derived rock (SB), and some minor amounts of mixing between the two.

Volume estimates can only be approximate, as the thickness of the deposit is poorly constrained (Wadge et al., 1995), and there is considerable variation in the thickness of separate units. Our estimates here are a refinement of previous ones, due to the increased vertical data provided by new roadcuts, but they are not final.

We estimate, using all available outcrops, the average SB thickness in the El Cenizal unit to be $2 \mathrm{~m}$. Estimating the Monturaqui unit thickness is more difficult, as the base does not generally out crop in road cuttings. However, $15 \mathrm{~m}$ is probably a reasonable upper estimate, based on the total thickness of the avalanche deposit (Wadge et al., 1995). We arrive at a total SB volume of about $5.5 \mathrm{~km}^{3}$, with no allowance for volume increase from intact to fragmented rock. Even so, this estimate is smaller than our independent estimate of the scar wedge volume of about $6 \mathrm{~km}^{3}$; the remaining volume probably resides in the toreva blocks. With a SB estimate of $5.5 \mathrm{~km}^{3}$, the volumetric proportion of Salin substrata is therefore likely to be about $20 \mathrm{~km}^{3}$ ( $80 \%$ of the total avalanche $25 \mathrm{~km}^{3}$, excluding the toreva block $11 \mathrm{~km}^{3}$ ).

Our uncertainties remain on the order of $30 \%$ for the SB volume, due to the difficulty in determining thickness. The main source of overestimation of the SB in the El Cenizal unit is the large quantity of Socompa-like clasts in the Salin gravel and boulder beds. A large proportion of the surface layer on the El Cenizal unit may be made of this material. Some of the RIFSB may be Salin gravel layers mixed with RIF. The major source of underestimation of RIF content comes from the removal of fine, loose RIF from the deposit surface. In cuttings, RIF disturbed by roadcuts forms banks of very mobile and porous dust, easily disturbed. Such a mantle may have covered much of the avalanche, probably now removed by wind. On El Cenizal unit margins remnants of this cover are still preserved (Fig. 6e). 


\subsubsection{Features of the proximal, northeast-directed El Cenizal unit}

The curious northeast-directed proximal part of the El Cenizal unit is composed of a partially disaggregated lava flow, recorded by Ramirez (1988) as the $\mathrm{EC} 1$ of the El Cenizal Unit. The more distal parts and the levees are solely of RIF material.

The EC1 lobe is notable for an elevated margin up to $200 \mathrm{~m}$ above the present interior part of the deposit. This blocks the valley entrances but does not run up valley, indicating movement along the main northeast-trending topographic scarp. The margin has a well-preserved slope and levee, but is separated from the interior of the deposit by several large-throw normal fault scarps (Fig. 8).

On aerial photographs (Fig. 8), discrete areas of EC1 have a surface pattern similar to that of intact lavas below the north flank of Socompa and adjacent toreva blocks. The surface is also cut by many sharp scarps, spaced 50-200 $\mathrm{m}$ apart. On the ground we observed that the surface was formed of low ridges, 2-5 m high, trending generally east-west, and steep scarps up to $40 \mathrm{~m}$ high, which mostly trended northsouth. The highest scarps are found along the eastern

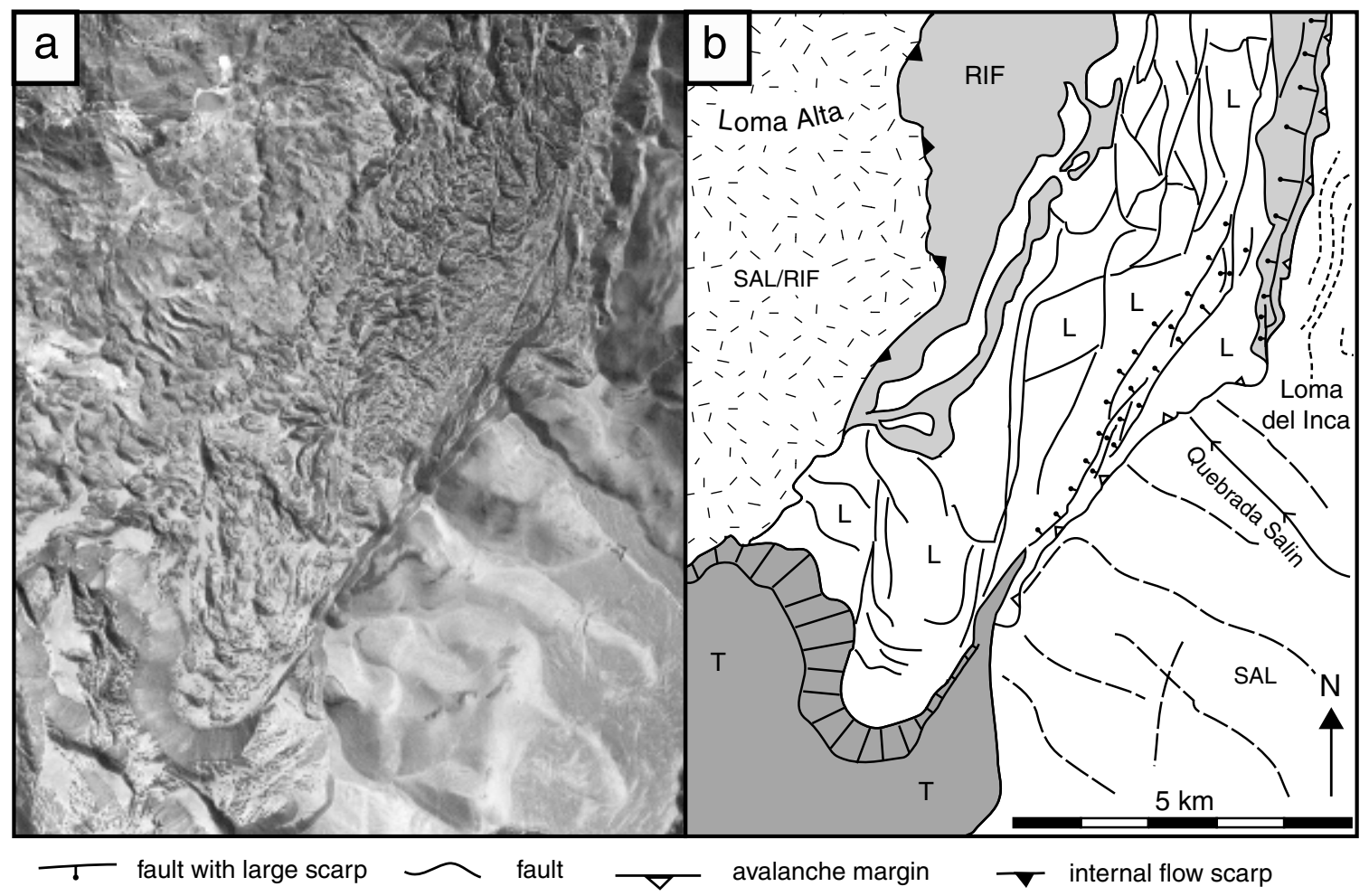

.... strata lineation on Loma del Inca _ _ Ridges south and north of Quebrada Salin

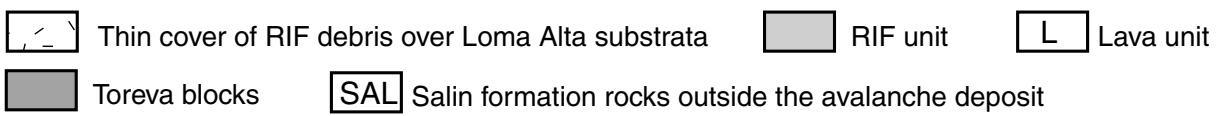

Fig. 8. Aerial photograph (a) and sketch (b) of northeastern margin of toreva blocks and part of avalanche deposit. This figure illustrates the type 3 toreva margin. Smooth, curved edge of torevas is seen lower left, with broken up lava flow extending north-north eastwards. Large throw faults (up to $100 \mathrm{~m}$ ) along the deposit margin are shown. These separate the deposit margin from the inner surface by approximately $200 \mathrm{~m}$ in height. Margin runs along the contours of Loma del Inca, indicating transport across hillside, rather than banking up against topography. Surface composed only of RIF is found at margin and to the east. An internal flow scarp separates this from a thin veneer of RIF overlying Loma Alta. The figure also shows strata outcrop near Loma del Inca and ridges south of Quebrada Salin, which may be expression of folding. 
margin $2-4 \mathrm{~km}$ from the toreva blocks. On the flanks of the scarps we observed some outcrops of RIF and evaporite blocks. This morphology continues about $10 \mathrm{~km}$ northwards from the toreva blocks to where there is a tongue of lava-covered material extending westwards. On aerial photographs this tongue has a chaotic surface texture, distinct from the rest of the unit. We interpret the low east-west ridges as relict lava flow morphology, the north-south scarps as faults cutting the lava flow, and the tongue texture as a fully disaggregated flow. This interpretation implies that the lava flow was rafted on the avalanche and that portions remained intact even after $200 \mathrm{~m}$ of deflation.

\subsubsection{Evidence relating to fragmentation of material}

Outcrops of RIF very rarely contain intact blocks of Salin rock, and these are limited to proximal areas such as the Lion's Paw (Fig. 5), or distal areas where the avalanche bull-dozed salar sediments (Wadge et al., 1995). It is surprising that the ignimbrite strata are so rarely seen intact, as many other debris avalanches preserve considerable quantities of relict bedding (Siebert, 1984). Elsewhere RIF resembles Salin ignimbrite, but there are distinct differences:

(a) the RIF contains gravel- to boulder-size clasts of andesite and dacite, similar to that found in the Salin gravels and Socompa clasts;

(b) RIF lacks pumice clasts which are common in Salin ignimbrite layers (compare Fig. 6a with Fig. 7a);

(c) layering in the RIF, where found, is discontinuous and the boundaries between layers are indistinct, wavy and wispy appearing fluid-like (Fig. 6b). Commonly one layer pierces another with diapiric structures (Fig. 6a and c);

(d) previous stratigraphy has been obliterated, though a new foliation or banding can be sometimes found (Figs. 6 and b);

(e) the RIF is dominantly (about $80 \%$ ) composed of ash size particles.

The material at the contact between SB and RIF often has evidence of brittle behaviour, with faults and rotation of blocks usually indicating shear between RIF and SB (Fig. 7b). Between the volcano and the secondary scarp the faults are consistently normal, and all observed occurrences dip away from the volcano. If viewed from the southeast, the rotation sense of intervening blocks is anticlockwise (Fig. 7b).
To produce this sense of shear the underlying RIF must have been moving at a greater rate than the SB above. The lower RIF facies travelled the furthest and it forms all the distal lobes (Fig. 5), which also indicates that it was more mobile than the overlying SB material.

On very close inspection, the contact between SB and RIF contacts display wispy mixing features, indicating local fluid-like behaviour (Fig. 6a, c and d). The banding shown in Fig. $7 \mathrm{~b}$ separates one size range of fragmental material from another. It is different from any banding seen in in situ Salin ignimbrite, but instead appears to be a product of fluid-like granular flow. Brittle structures are most prevalent in the Monturaqui unit, and the notable ridges in the avalanche surface in this unit (Francis et al., 1985) are probably surface expressions of faults such as those shown in Fig. 7b.

These observations lead us to propose that the RIF was formed by complete fragmentation of Salin ignimbrites and gravels, but with only very limited intermixing of Socompa edifice material.

\section{Structural geology in and around Socompa}

The structure and morphology of rocks northwest of Socompa are characterised by folds, thrusts and elongate hills. No evidence of deformation is found to the south and southwest of Socompa, where the metamorphic and igneous massif of Sierra de Almeida runs close to the volcano (Figs. 2 and 5). We examined in detail three distinctive structural ridges to the north and northwest of Socompa, and outcrops at the base of some torevas.

\subsection{Altos de Inca Anticline}

The Altos de Inca has a steep, $300 \mathrm{~m}$-high, westfacing scarp onto which the Socompa avalanche onlaps (Fig. 5b, point a). Rocks exposed in gullies in the scarp dip concordantly with the slope at about $45^{\circ}$ west and become less steep as the flat top of the hill is approached. The top of the hill dips slightly to the east for $2 \mathrm{~km}$ and then at a sharp break of slope drops more steeply eastwards (Fig. 5b, point b). Toward the south, the ridge splits into several smaller scarps on which inclined bedding can be traced on aerial photographs. Two scarps trend south-southeast 


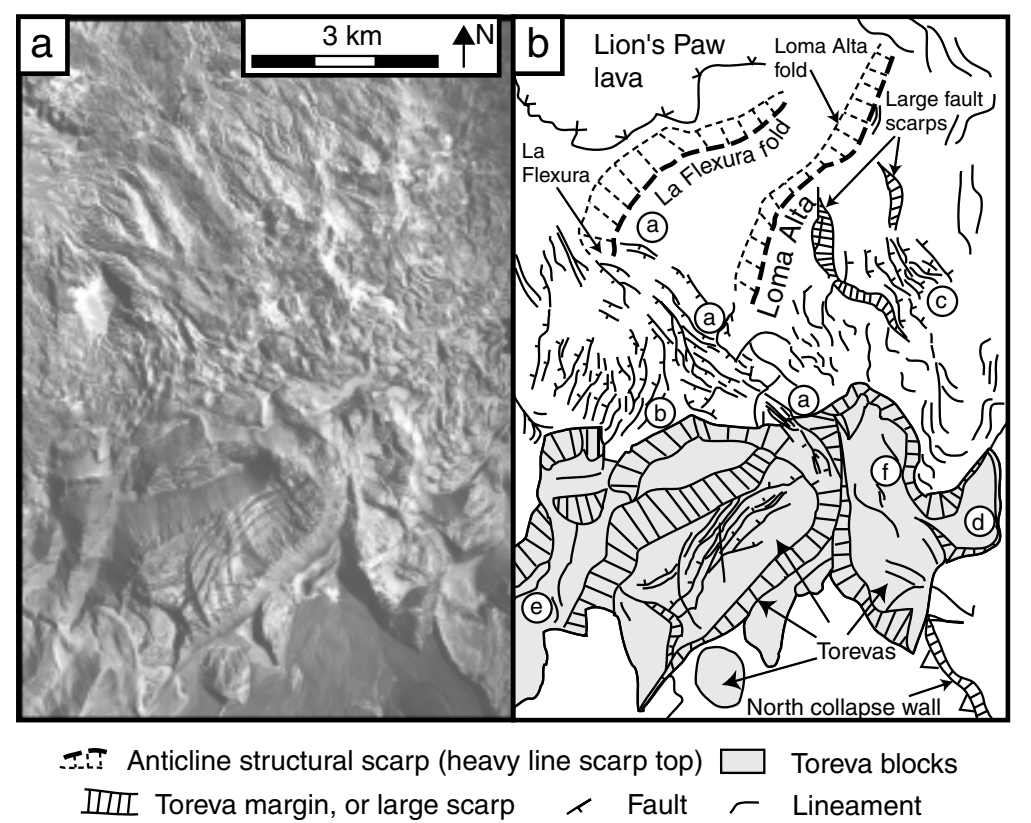

Fig. 9. Aerial photograph (a) and interpretation of west and north-west margin of avalanche scar, including La Flexura, margin of toreva blocks, and Loma Alta (b). The location is shown in Fig. 4. Encircled letters indicate: (a) area of faults following strike of scar margin; (b) area of faults in substrata and avalanche at right angles to the scar; (c) northeast facing fault scarps in Loma Alta substrata; (d) simple 'slide-to-stop' type 1 toreva margin; (e) type 2 margin; (f) type 3 toreva margin. The area occupied by toreva blocks is shaded.

(Fig. 5b, point c), while another crosses and cuts these following a similar trend to Altos de Inca. Another continues south-southwest, abutting the slopes of Socompa (Fig. 5b, point d).

\subsection{Loma Alta Ridge}

To the west of Altos de Inca there is a second, lower ridge, on which occasional outcrops of Negrillar lava and Salin beds are seen (Fig. 5b, point e). The shape of this ridge indicates that it is probably another fold. The northeast slope of Loma Alta is a scarp, created by several faults (Fig. 9) that cut the avalanche surface. This indicates that Loma Alta partially collapsed to the northeast during, or just after avalanche emplacement.

To the south, next to the toreva blocks, Loma Alta and the avalanche surface are also cut by numerous faults. These faults are parallel to the collapse margin between La Flexura and the scar in the volcano. To the south of this line, the faults become normal to the collapse margin, and to the direction of avalanche transport (Fig. 9, point a). The orientation and sense of movement of these faults are an indication that the Loma Alta Ridge collapsed during the avalanche event. If this is correct, then the ridge formerly extended around the removed foot of Socompa. However, there is no sign of this anticlinal hill extending to Monturaqui, south of the collapse.

\subsection{La Flexura folds}

Within the Socompa debris avalanche there are several inliers of in situ rock, most of which are outlying lavas from the Negrillar field (Ramirez, 1988). The exception is La Flexura, a $150 \mathrm{~m}$ high cliff of Salin beds (Fig. 10) that preserves $\sim 2 \mathrm{~m}^{2}$ of preavalanche surface under only a thin veneer of avalanche debris. La Flexura is named after a broad fold in the Salin beds exposed in the cliff (Fig.10). This fold and another more easterly fold can be traced for $5 \mathrm{~km}$ to the north along an irregular shallowly dipping scarp (Fig. 5b, point g and Fig. 10). On the southeast side of La Flexura, the Arenosa Ignimbrite within the Salin Formation (Ramirez, 1988) and gravel layers are overturned in a recumbent fold 


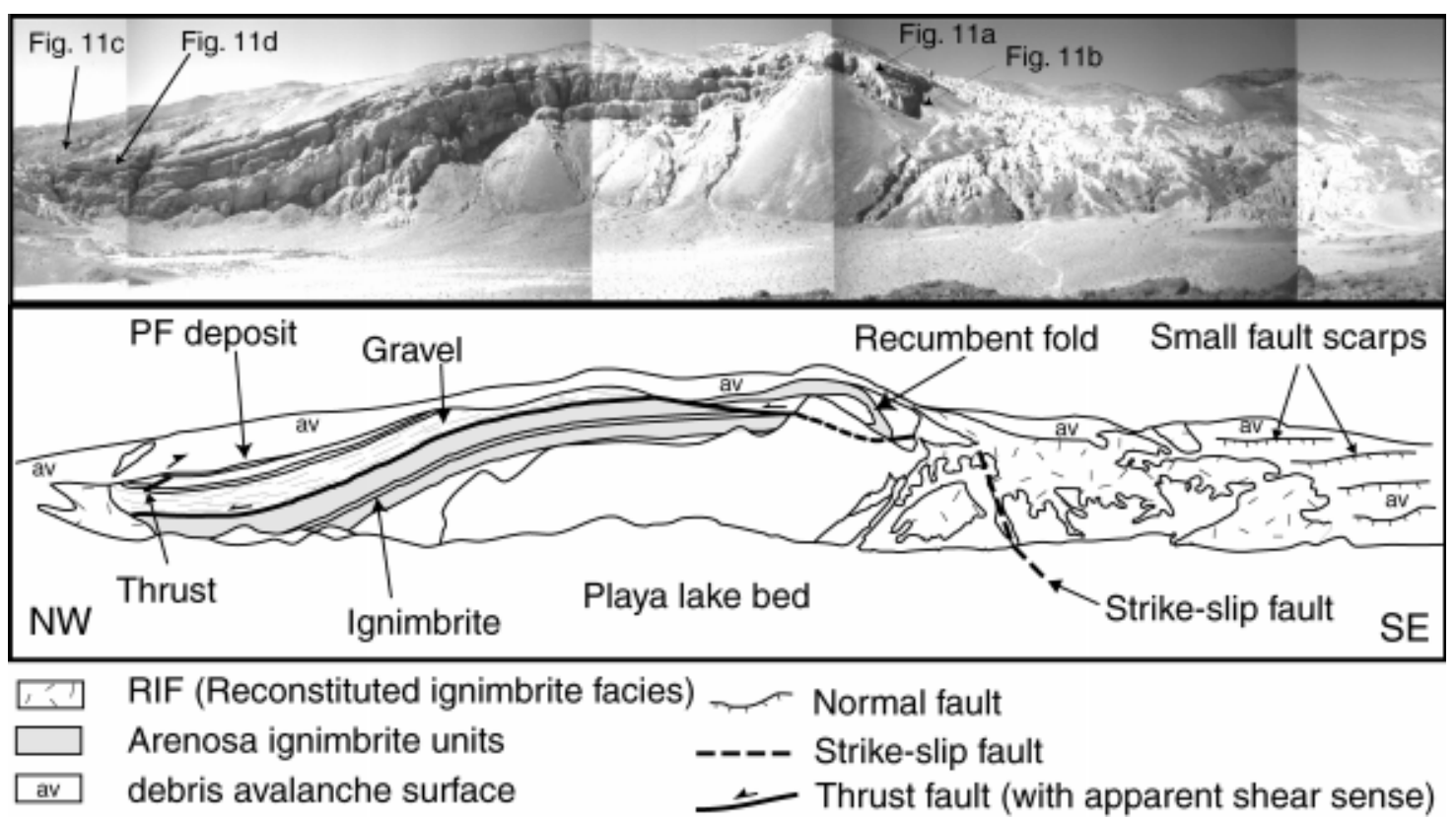

Fig. 10. Panorama and sketch of La Flexura outcrop, showing major structural features. The view is about $1.5 \mathrm{~km}$ wide, and the cliff $150 \mathrm{~m}$ high. The locations of photographs in Fig. 11 are shown. Note that sense of fault movements in the section are apparent, as seen in plane of section.

verging northeast towards Pajonales. The basal detachment of this fold can be traced through the La Flexura cliff (Figs. 10 and 11a, b).

The north end of the cliff reveals a coarse pyroclastic flow deposit, composed of Socompa-like andesite blocks in a pumice matrix. Conglomerates with Socompa-like petrographic characteristics overlie this. Gravel layers below this contain finely laminated shear zones, and views of the cliff show that the pyroclastic flow deposit is cut by small thrusts (Fig. 11c and d). If this is a Socompa-derived pyroclastic flow, then deformation was occurring during the growth of the edifice.

At the south base of La Flexura a steep slope is underlain by coarse conglomerates, dipping $30^{\circ}$ north-west, cut by south easterly trending vertical faults, with horizontal slickensides (i.e. strike-slip faults) (Fig. 10). La Flexura is the lowermost structural feature of the compressional structures seen and may be the frontal fold of a belt that was actively forming during the building of Socompa volcano.

\subsection{Structures exposed within the collapse scar}

Exposures of Salin Formation are found at the base of some toreva blocks (Fig. 5), where light coloured streams of RIF material extend out into the avalanche deposit (Fig. 1, point s). At these locations, massive pumiceous ignimbrite is found, probably not in place, but intact over $30 \mathrm{~m}$ stretches. Within the ignimbrite there are distinct shear zones, toward which round pumice clasts are progressively flattened and rotated into alignment (Fig. 7a). The shear zones are composed of fine-grained, finely laminated material. At other outcrops, a dense network of fractures of all orientations breaks up the ignimbrite, such that it can be crumbled by hand (Fig. 7c). The shear zones indicate that gradual plastic deformation was occurring under the flank of Socompa before collapse, whereas the highly fractured areas are probably related to break-up during avalanche motion.

\section{Structure and morphology of the toreva blocks}

The structure and morphology of the toreva blocks preserve evidence of fragmentation of the volcano and interaction of mobilised substrata with the volcano during collapse. The lower toreva blocks have three 

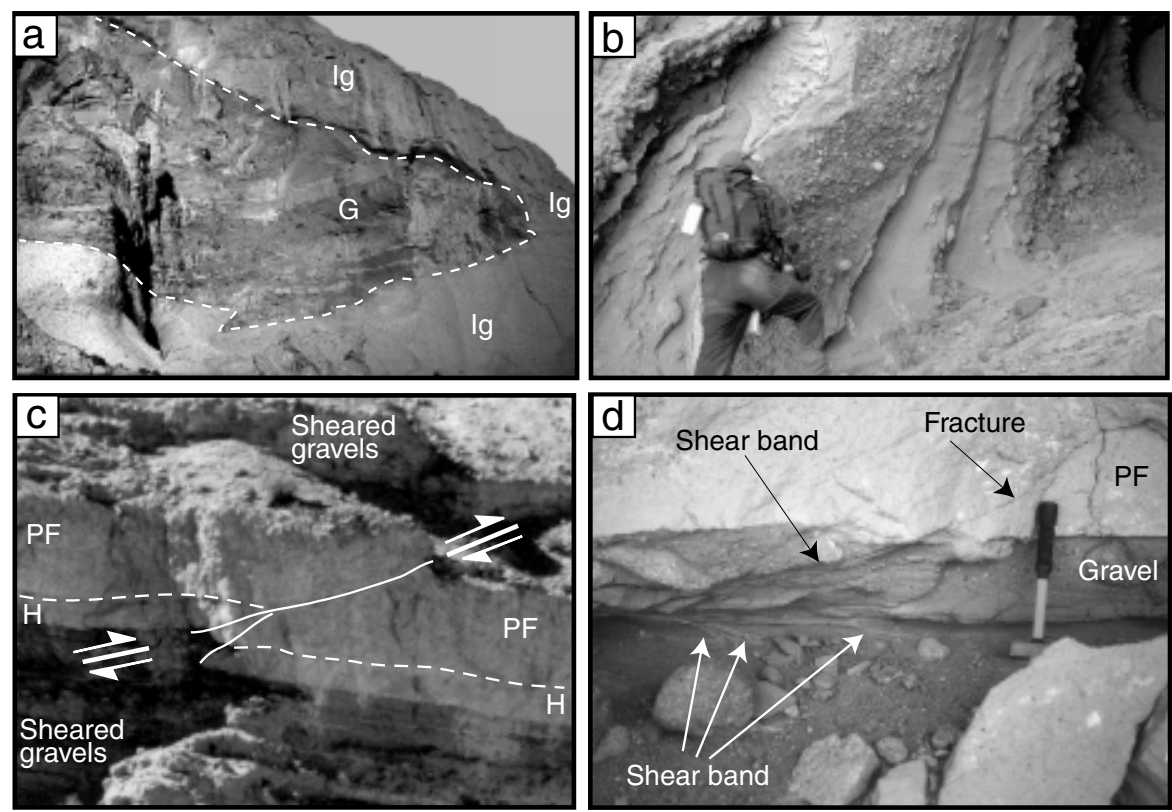

Fig. 11. Field photographs of structures at La Flexura. (a) Nose of recumbent fold in Arenosa ignimbrite (Ig), with strongly deformed layered gravels in core (G). Field of view $50 \mathrm{~m}$ across. (b) Near vertical gravel beds in nose of recumbent fold. (c) Small thrust in $3 \mathrm{~m}$-thick block and ash flow layer (PF). H indicates a horizon in PF. (d) Shear bands in gravels below the block and ash flow.

types of morphologies, indicating different modes of fragmentation:

(1) Intact. This type of block is found on the northeast and northern margin of the collapse scar (Fig. 9, point d). Those of the northern margin have slid over the collapse scar wall onto the volcano flank and form the avalanche front.

(2) Blocks which become progressively more densely faulted away from the volcano, broken into increasingly smaller slices. This type is found to the West (Fig. 12). The few windows of substrata that appear under torevas are connected to light colored RIF bands, with no Socompa rock covering (Fig. 1). In the intervening areas the Socompa debris (SB) forms only a thin covering on the RIF.

(3) Blocks that have sharp, arcuate and eroded margins. This type is restricted to north facing blocks (Figs. 8 and 9). This type of toreva margin is at the source of the curious deviant salient of the El Cenizal (EC1) that flowed northwards (Fig. 3). Here, there is no progressive faulting and the morphology is simple. The margin of the torevas is a smooth, regular slope. In plan view the margin is curved and has one pronounced embayment (Fig. 8).

\section{Discussion}

The fundamental hypothesis of this paper is taken from van Wyk de Vries and Francis (1997). It is that the great predominance of substrata in the avalanche deposit is causally related to the gravitational spreading structures. Thus, we consider here whether spreading created the avalanche. This section discusses the consistency of the hypothesis considering the available observations presented above.

In order explain how the collapse formed, several important features require explanation:

(1) the spatial and temporal relationships of gravity spreading structures to the avalanche;

(2) the large proportion $(80 \%)$ of substrata in the deposit;

(3) the fragmentation and mobilisation of the ignimbrite and gravel substrata;

(4) the fact that the substrata components with the least potential energy travelled farthest;

(5) the fact that the substrata remained mainly as a separate layer at the base of the avalanche;

(6) the fact that the northern debris flow travelled almost at right angles to the main flow. 

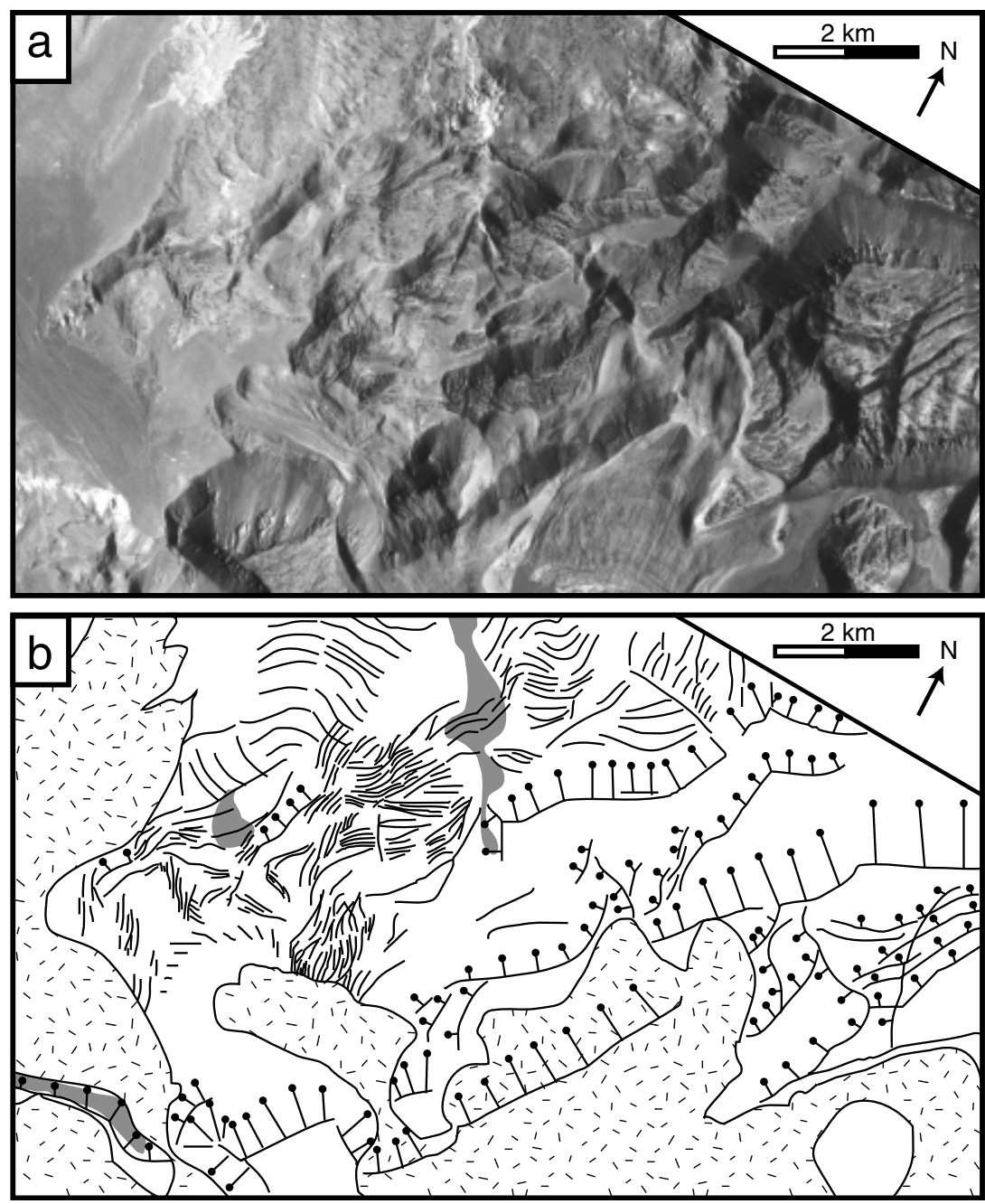

Fig. 12. Aerial photograph (a) and sketch of faulting (b) at collapsed margins of central toreva blocks. This figure illustrates the type 2 toreva margin. Downthrow on large block margins and faults are indicated by bar and ball. For smaller faults, the throw and dip are generally down to the east or northeast (upper left or top). Shaded areas pick out substrata and RIF outcrop, and speckled areas represent post-collapse material.

\subsection{Possible mechanisms for sector collapse at Socompa volcano}

Gravitational spreading is a consequence of the growth of a volcano on a weak substratum; the loading results in deformation of the underlying rocks. The nature of the deformation depends on the material properties of both volcano and substrata. If the volcano's core is weak it may be involved in the deformation and spread laterally (Merle and Borgia, 1996; van Wyk de Vries et al., 2000). The substrata (and lower part of the volcano) will initially respond to loading with an elastic response and by compaction. Subsequently, the substrata may deform gradually in a more plastic or ductile manner (Van Bemmelen, 1970; Nakamura, 1980; Merle and Borgia, 1996). If there is a thin ductile layer, or decollément(s) below the volcano, then the substrata spread laterally away from the cone (Merle and Borgia, 1996; van Wyk de Vries and Borgia, 1996). This can lead to two styles of deformation dependent on whether the volcanic edifice spreads with the substrata ('volcano spreading'), or 


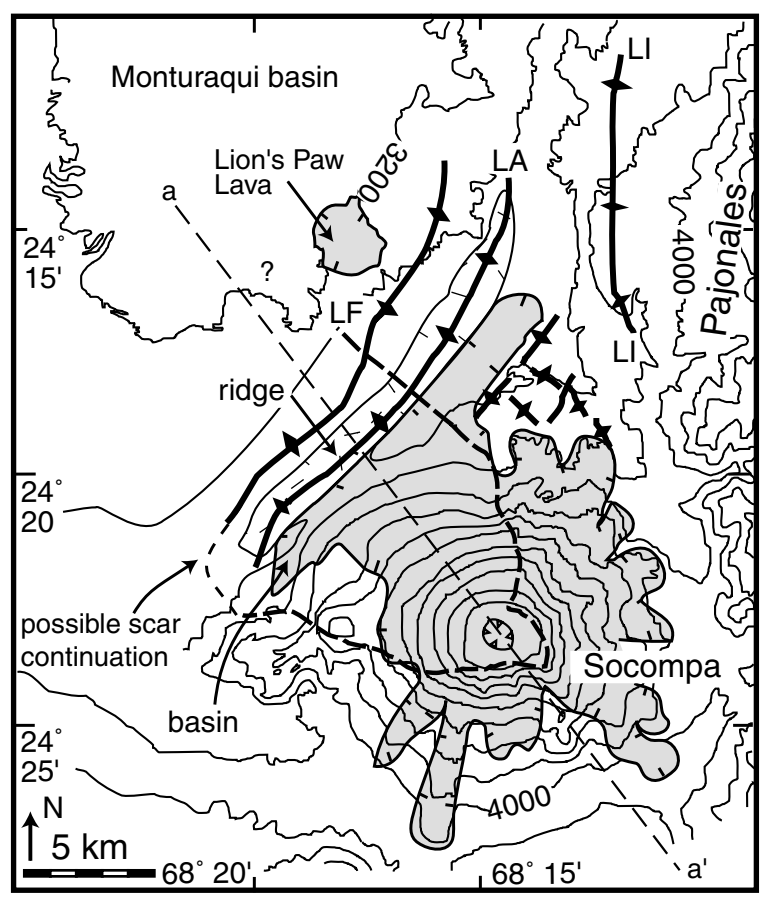

Fig. 13. Reconstruction of Socompa topography and structure before sector collapse. The volcano stood high above the south east edge of the Monturaqui basin. La Flexura (LF) and Loma Alta (LA) anticlines extended round the north west base of volcano. Reconstructed Loma Alta Ridge is stippled for emphasis around the $3600 \mathrm{~m}$ contour. Lava flows emplaced a short time before collapse are shaded. The exact distribution of these within the scar is speculative. Those lavas that flowed to the north are diverted by the Loma Alta Ridge. The position of these lavas is well constrained, as they were not transported far in the collapse. They are now seen as the northeastern toreva blocks and the lava rafted on the EC1 (Fig. 8). Loma del Inca anticlinal hill is also shown below Pajonales volcano, and possible anticlinal hills between the two volcanoes are also shown. Border of collapse scar is shown as a dashed line. Dotted line $\mathrm{a}-\mathrm{a}^{\prime}$ indicates line of section in Fig. 14.

whether the volcano and substrata are decoupled, in which case the substrata are extruded from under the cone: ('substrata extrusion') (van Wyk de Vries and Matela, 1998). In either case, a compressional fold and thrust belt is produced at the foot of the volcano, due to the outwards-directed lateral transport. During volcano spreading, the edifice gets flatter and wider and is cut by extensional faults. In contrast, with extrusion, the volcano remains steep and is subject to shear stresses that can produce compressional faults within the edifice (van Wyk de Vries and Matela, 1998).
The role of a mechanically weak substratum in promoting sector collapse was recognised at Mombacho volcano, Nicaragua, where the collapse scar cut deeply into the underlying ignimbrite, allowing large amounts of substrata to be incorporated into the avalanche deposit (van Wyk de Vries and Francis, 1997). Weak substrata enhance the likelihood of collapse, because they extrude at a high rate and produce large slope-parallel shear stresses in the edifice (van Wyk de Vries and Matela, 1998).

\subsection{Structural synthesis}

Within the La Flexura-Loma del Inca area there is a fold and thrust belt with three main folds: Loma del Inca, Loma Alta, and La Flexura. There is no morphological evidence of deformation further west of $\mathrm{La}$ Flexura and so it probably is the deformation front. The fold belt's orientation and its restriction to the volcano base suggest that it is directly related to the presence of Socompa and Pajonales volcanoes. The westernmost two structures, La Flexura and Loma Alta, are both cut by the Socompa avalanche scar, and originally probably extended some way around the base of the volcano (Figs. 5 and 13). The shear structures found in intact ignimbrite under toreva blocks indicate that deformation extended this far. There is, however, no structural or morphological evidence that the structures continue on the southeast side of Socompa.

Thrust vergeance, shearing directions and trends are variable. The Loma del Inca trends north, tangential to Pajonales Volcano. Loma Alta and La Flexura swing around to the northeast, approaching tangential to Socompa and parallel to the sector collapse mouth (Fig. 3). Some structures at La Flexura, such as the recumbent fold, are tangential to Pajonales, which may indicate that La Flexura and Loma Alta belong to a second phase of deformation altering original spreading structures from the older Pajonales. The area between Socompa and Loma del Inca contains a series of ridges, both radial and tangential to Socompa, which may represent a zone of structural interference between the two volcanoes.

An alternative explanation for recumbent folding at La Flexura is that it is the product of transpression along a strike-slip fault separating two spreading sectors. Strike-slip faults are a common accompaniment to 
a
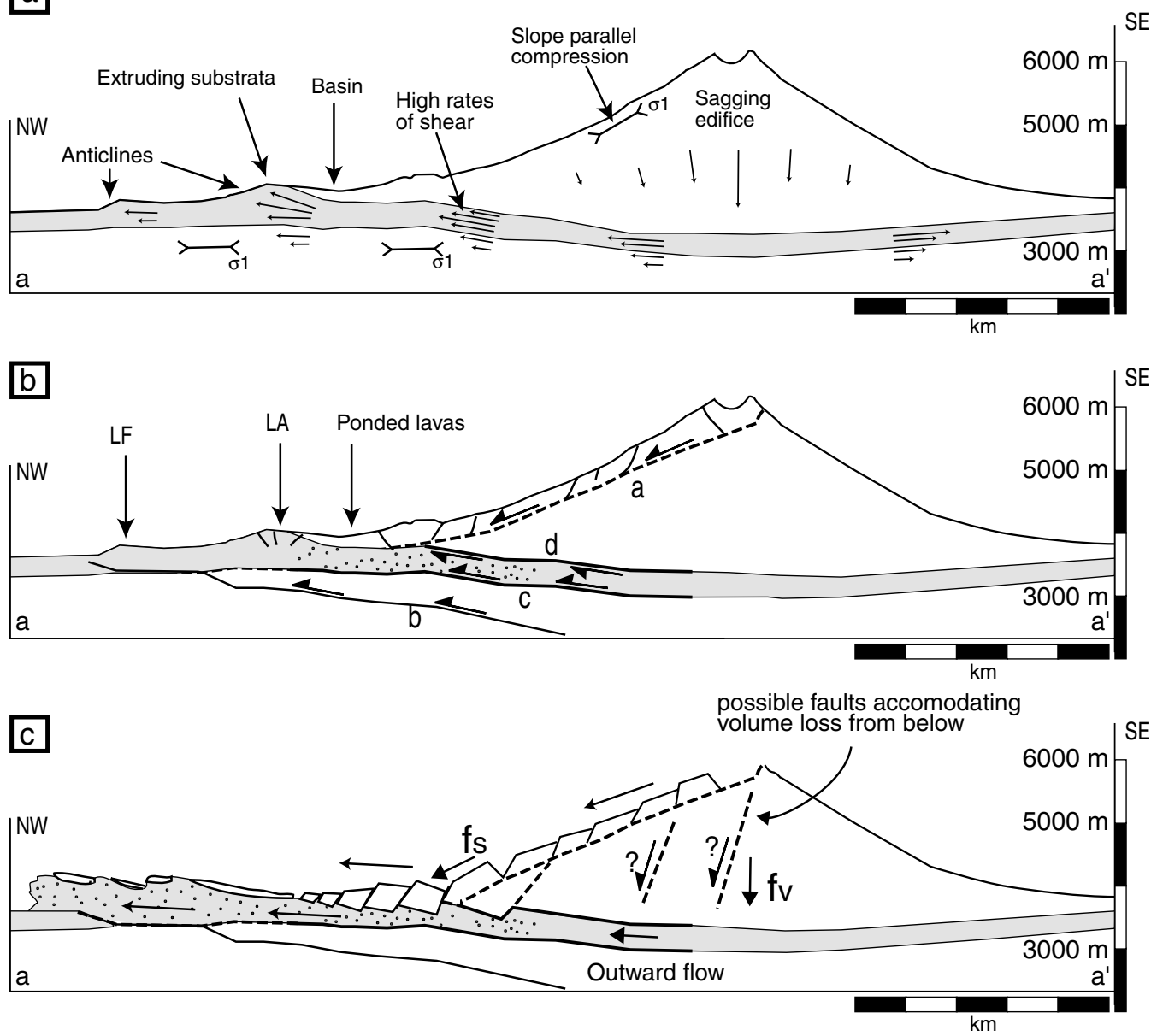

Fig. 14. Sections through reconstructed cone of Socompa. Topography is estimated by tracing contours round from one side of collapse to another. (a) Diagram showing process of substrata extrusion postulated for Socompa. Volcano loads substrata, which respond by squeezing out from underneath. Substrata may deform on few major shear zones or pervasively. As the cone is relatively strong compared to the substrata, it does not spread, but sags downwards and inwards. This leads to high compressive stresses parallel to cone surface. (b) Interpretative diagram showing potential collapse slide plane: (a), thrust-anticlines and probable location of the Salin beds, with shearing sense along potential zones of weakness; (b), possible thrust rising from substrata below Salin Formation; (c), Possible shear between Salin Formation and lower units; (d), Possible shear between Salin beds and the Socompa edifice. Note that due to extrusion the latter has the opposite sense to lower shears. Dotted area indicates possible substrata volume ejected by mobilisation during the avalanche. (c) Interpretational section of development of sector collapse through substrata mobilisation and shallow sliding. Toreva blocks form, slide down and disaggregate onto the avalanche as mobilised substrata is extruded. Main driving forces involved in collapse are illustrated conceptually: the force from sliding sector (fs) and forces from gravitational loading and deformation response (fv).

spreading-related thrusting (van Bemmelen, 1970; van Wyk de Vries and Borgia, 1996), and vertical faults below La Flexura have horizontal slickensides (Fig. 10). Any deviation from a radial orientation on such faults or interference from more than one stress source (Socompa and Pajonales Volcanoes) is likely to cause transpression along strike-slip sector bound- aries. This will result in thrusting and folding along the fault zone.

We have reconstructed the pre-collapse structure and topography of Socompa using such evidence as the truncated Loma Alta and La Flexura anticlines and the shearing found in Salin beds below torevas (Figs. 13 and 14). From the reconstruction we can 
estimate the volume of lost substrata material. The detachment plane may have followed the frontal La Flexura thrust, which probably steps down toward the volcano (Fig. 14b, decollement b). Alternatively, it may have followed a more horizontal or climbing slope (Fig. 14b, decollement c). This latter scenario may be more likely as no deeper strata, from below the Salin Formation, are included in the avalanche.

With a horizontal plane, we calculate a rough initial volume of the substratum component by a $8 \mathrm{~km}$-long slice, $10 \mathrm{~km}$ wide and with a thickness of $300-400 \mathrm{~m}$. This gives $24-32 \mathrm{~km}^{3}$, roughly similar to that estimated above for the basement component in the avalanche. Calculation can only be approximate, as there is little constraint on the original surface topography, or the exact depth of the failure. The role of bulking of the basement component is also difficult to assess; however, as the original Salin deposit is roughly as porous as the RIF we have neglected this complication.

\subsection{Interpreting the toreva structure}

The first (simplest) toreva block margin type has undergone minimal disruption and was probably formed by blocks simply sliding a short distance downslope. For the second margin type (Fig. 12), the increase in fault density may be explained by material moving progressively faster further away from the block, and a decrease in thickness of a brittle top layer carried on a ductile, or fluidised layer of Salin Formation. The latter would require a catastrophically extruding mobilised layer below the toreva blocks. This hypothesis would also have the toreva blocks contributing material to the upper layer of the avalanche, forming the SB material. It also implies that the blocks slid as the avalanche was developing, rather than slipping down afterwards. In this model, they are integral to the development of the avalanche.

The third margin type (Figs. 8 and 9) is at the origin of the north-flowing salient. We consider four pieces of evidence to be significant for its interpretation:

(a) the degree of surface fragmentation is much lower than elsewhere, indeed the avalanche may even have preserved some relict surface features of the lava flows;

(b) the surface texture of unaffected lava flows on the north flank, the toreva blocks and the lava unit of the avalanche are similar. Although, in the latter case they are cut by many large faults (Fig. 8). This indicates that the lava flow remained partially intact as it rafted on top of the RIF;

(c) the orientation and the large throws of the faults (Fig. 8) point to major proximal deflation of the deposit;

(d) the elevated east margin has indications of slope parallel momentum-dominated transport and lateral flow across valley mouths (Fig. 8). This implies that the initial avalanche surface was level with this margin.

We consider that the points (a) and (b) indicate that the EC1 lava has not been transported far from its original position, and that it originally occupied the valley between Loma Alta and Altos de Inca. Points (c) and (d) indicate that, during its initial emplacement, the avalanche surface was 100-200 m higher than at present.

To account for the large drop in level of the avalanche we suggest that a large volume of substratum material passed out from underneath the lavadominated surface. This travelled on to form the main part of the EC1 deposit. As this was going on, the northeastern toreva blocks were faulted and the lower lava flow unit was rafted on the extruding substrata. The load of the emplaced avalanche may then have contributed to the coeval partial collapse of the Loma Alta.

We envision that the mobilised substrata was ejected from underneath toreva blocks as they were sliding down. The lower parts of the blocks would have been carried out on top of the extruding substrata to form the upper Socompa-dominated unit of the avalanche (SB).

\subsection{Style of spreading: substrata extrusion at Socompa}

For a volcano to spread on its substrata, the substrata must contain a layer weak enough to deform at a geologically significant rate under the load of the edifice (Nakamura, 1980; van Wyk de Vries and Matela, 1998). A significant rate is one that produces structures before other processes, such as erosion or caldera formation, remove the loading. The Salin Formation is composed of weak rocks and they exhibit an abundance of deformation structures. Erosion is 
very slow in the region and Socompa has not been disrupted by caldera collapse. Thus, the Socompa situation is ideal for undergoing spreading.

There is no evidence of spreading-related extension on the cone of Socompa, and evidence of only minor faulting on Pajonales, yet both have basal spreading structures. Such a situation could be produced by continual resurfacing of the volcanic edifice, such as at Concepción, Nicaragua (van Wyk de Vries and Borgia, 1996). However, because there has been no activity at Pajonales for many thousands of years, this cannot apply here.

Regional compression might produce thrusting without extension in volcanoes, but as there is no evidence of large regional structures, and as the deformation is restricted to the ductile cover rocks, we consider this an unlikely explanation.

Another way of producing basal thrusts with little apparent volcano deformation is if the substrata extrude from below the edifice (van Wyk de Vries and Matela, 1998). In such a case, the volcano is coherent and strong in relation to substrata, and so it does not break up. Instead, the edifice sags downwards as substrata squeezes out from underneath. The upper part of the volcano is compressed, with slope-parallel maximum compressive stress (Fig. 14a).

Large, coherent dacitic lava flows cover much of the surface of Pajonales and Socompa, and the Socompa collapse scar exposures are lava dominated. Such a construction is likely to be strong and coherent, creating optimum conditions for substrata extrusion. We have presented evidence above of substrata deforming prevasively, by folding and by thrusting. Because of this we interpret the structures at Socompa and Pajonales as being a result of substrata extrusion (Fig. 14b).

\subsection{Styles of thrust anticline development}

There are considerable differences in the structural style and amplitude of spreading features around Socompa and Pajonales. In this section we discuss why there is a variation and consider the relationship of different styles to sector collapse. We divide the area up into four distinctive sub-areas (Figs. 3 and 5).

1. Monturaqui: no deformation visible; here the Salin beds of Arenosa ignimbrite dip gently northwards.
2. La Flexura-Pajonales: well-developed structural uplift and thrusting, with the Socompa sector collapse (Fig. 5).

3. Negrillar: slight uplift and folding, normal faults over fold hinges, little deformation after the Negrillar lava field emplacement.

4. Northwest Pajonales: structural uplift and thrusting. In this area there are a number of well-developed thrusts and anticlinal ridges (van Wyk de Vries et al., 1996).

In the case of Monturaqui, the volcano abuts the granite basement massif of the Sierra Almeida. Here, the lack of deformation can be correlated with the absence of a deformable layer.

For areas 2 and 4, the structures are well developed and the deformable layer is the Salin Formation. In these areas, an elongate basin is formed behind each anticline, in which sediments and lavas have collected. The basins may contain several $\mathrm{km}^{3}$ of material, the load of which will increase deformation and make anticline failure more likely.

For area 3, the Negrillar lava field, there is a much more subdued style of deformation. There is uplift and Salin strata are steepened into a broad fold, while normal faults have developed over the hinge. We have not located any faults cutting the fresh lava flow surfaces, so no large-scale deformation has happened after their eruption. To explain the lack of deformation we suggest a counterbalancing operation, by which the lavas have increased the mass enough to offset the load from Pajonales, thus restricting deformation and stabilising the volcano.

In conclusion, where there are deformable substrata, spreading structures are observed. Their amplitude and style are dependant on the local conditions: if the rising anticlines are loaded on top, or buttressed by other material (such as the Negrillar lavas), then spreading is inhibited. Where anticlines form they can collect lava and sediment behind them. Ponded material adds an extra load behind the anticlines, which will increase rates of movement and contribute to the collapse process. We do not know the actual extent of the loading effect, but point out that a similar effect has been shown to be important in foreland thrust regions (Merle and Abidi, 1995). This topic requires more study, probably by an analogue and numerical approach. 
5.6. Evidence for the behaviour of substrata rocks during spreading

In this section, we consider the evidence for the material behaviour of the Salin Formation during spreading. We also propose a possible process for the mobilisation of ignimbrites under the high shear stresses and high strain rates expected during spreading.

The Salin Formation can be divided into two basic rock types: pyroclastic flow deposits (ignimbrites and lithic-rich pyroclastic flows), and coarse sediments (gravels and conglomerates). The small lenses of evaporites present in the Salin probably effect only localised deformation. The ignimbrites form a consolidated mixture of highly porous pumice and ash with a few lithics. The pumice clasts in the ignimbrites are less strong than the cement and are easily crushed. The rock cannot be fractured without breaking the clasts themselves. Thus, the strength of the rock is limited by the fragile pumice clasts. By contrast, the sediments are poorly consolidated and are composed of compact lithic clasts, with no pumice. In these beds, the clasts are stronger than the bonds between them. Both rock types are very porous.

Small-scale deformation features reflect the properties of the two rock types. The ignimbrite material has responded by clast deformation over broad zones (e.g. the reoriented clasts in Fig. 7a) and by clast fragmentation in discrete zones (e.g. the fine bands in the shear zone in Fig. 7a). Another style found at these outcrops is severe fracturing of the rock (Fig. 7c). This mode cuts shear zones and is a later feature. Such fracturing may be an intermediate stage between the intact sheared rock and the completely disaggregated avalanche material. The sediments have formed many small, closely spaced shear bands (Fig. 11d). The total displacement accumulated over these shears is considerable, judging from stretching, thinning and folding of enclosed pyroclastic strata (Fig. 11a and c).

Behaviour of strata is likely to be different beneath the cone (where volcano load is high) to that in developing anticlines (which are responding to push from behind). In addition, it is likely that different rates of shear developed and hence rock response differed as conditions for collapse developed.
We can deduce general material response beneath the cone from the type of spreading observed. The extrusion style of spreading inferred in the previous section requires weak, ductile substrata, capable of being squeezed out from under the cone. Direct evidence of ductile behaviour 100-300 m below the volcano flank comes from outcrops below toreva blocks (Fig. 7).

The La Flexura locality provides evidence of deformation behaviour in the spreading anticlines. Ductile behaviour is indicated by the large recumbent fold and shearing of gravels and ignimbrite (Figs. 10 and 11). This deformation must have occurred at less than $200 \mathrm{~m}$ depth.

From the above we deduce that the Salin Formation was able to behave in a ductile manner under shear at low confining pressures. Our field observations suggest that this deformation occurred in ignimbrites by break-up and deformation of weak pumice clasts, and in gravels by shearing between grains along many small planes.

Although the actual stress-strain behaviour of a Salin Formation ignimbrite is not known, as material tests have not been done, there are data for rocks that should behave similarly, such as chalk (Petley et al., 1992; Leddra et al., 1993). Chalk and ignimbrite are both composed of porous clasts, in the former case skeletal, in the latter pumiceous. Both rock types are poorly to moderately cemented, at least when considering Salin Formation ignimbrites. In both cases, clasts may be weaker than bonds between them, and clasts are likely to break and deform under stress (Petley et al., 1992).

Chalk has been observed to flow under the high strain rates of rock falls and under high deviatoric stresses next to oil well casings (Leddra et al., 1993). Material tests show that flow occurs under moderate confining pressures. The material deforms along its critical state envelope by strain softening. The rock fabric is progressively broken up and pore space is reduced. This process leads to high pore pressures and reduced effective stress. Eventually the rock changes structurally into a fully particulate material in its critical state, and undergoes flow. At optimum conditions for flow failure, the material deforms along closely spaced shear fractures separated by areas of pervasive ductile deformation (Leddra et al., 1993). Structures fitting this 
description are found in outcrops under toreva blocks (Fig. 7a).

The stress regime operating over volcano loading could produce the correct conditions for this type of failure: volcano loading produces high near-horizontal compressive stresses at low to moderate confining pressures (Merle and Borgia, 1996; van Wyk de Vries and Matela, 1998). There are therefore high differential stresses applied to the substrata, but low effective stresses. Such a situation will place rocks such as the Salin ignimbrites within their critical strength region. We suggest that a fruitful area for more research would be to obtain experimental data on the mechanical behaviour of the Salin rocks under appropriate mechanical loads.

\subsection{Processes of substrata failure and avalanche transport}

Transition from slow spreading to collapse probably was accomplished by the 'liquefaction' process described above. Several, none mutually exclusive, processes may have triggered the moment at which this occurred:

(1) There may have been progressive loading by continual eruption. Presence of fresh lavas on the intact edifice indicates that growth was rapid shortly before collapse, and that material was being erupted immediately beforehand. This lava could have been filling the basins behind thrust anticlines, thereby increasing loading (Fig. 13). This increased load raised differential stresses, increased strain, and could have triggered the failure.

(2) Shear softening may have lead to progressive loss of strength in the substrata (Leddra et al., 1993), leading to increased movement rates. The increased shear strain may have caused further strength loss, producing a positive feedback situation that "ranaway", leading to the catastrophic avalanche (Petley and Allison, 1997).

(3) The presence of water within the Salin Formation aquifer below the volcano would contribute to significant effective stress reduction during shear deformation (Leddra et al., 1993; Iverson et al., 1997). It is also possible that once rapid movement began, frictional heating could vaporise this water, providing an additional mobilising factor for the avalanche.
(4) The substrata may have been destabilised by an earthquake, resulting in increased movement along shear zones. Seismic loading can increase pore pressures and decrease the effective strength, triggering failure.

(5) Intruding magma could have been spreading underneath the volcano and forcing increased movement in the substrata, and raising pore pressure (Merle and Vendeville, 1995; Day, 1996).

The toreva blocks show signs of being progressively more broken up away from the volcano and extended by movement of substrata extruding from below. This fits with avalanche stratigraphy, where substrata form the basal and more distal parts. Shearing sense of SB material also indicates faster movement of lower RIF material (Fig. 7b).

We suggest that the substrata became mobilised, probably by breaking into a fine particulate material, and flowed (Leddra et al., 1993). This material was then extruded from under the volcano, generating edifice collapse and transporting Socompa material (SB) on top of a fluid layer (RIF). A fine, powdery layer of grains of similar size could be an efficient lubricator. Lubrication effects, such as granular temperature (Campbell, 1989; Cleary and Campbell, 1993; Iverson et al., 1997), and acoustic fluidisation (Melosh, 1979) are likely to be important in such a mixture.

Before collapse, the substrata were subjected to gravitational loading transmitted through solid rock. Once the collapsing sector wedge formed a basal slipplane, a component of the wedge load would be delivered to the frontal anticlines. This might have increased movement at the foot of the volcano foot, providing additional energy to the substrata on collapse (Fig. 14c).

The energy for the avalanche comes from gravitational potential and stresses maintained within the volcano and substrata. The latter are not distributed as a function of height, but depend on the deformation response (van Wyk de Vries and Matela, 1988). Because of this, the parts of the volcano with highest potential energy (i.e. the rocks at the summit) are not necessarily the ones to travel farthest. High stresses in the substrata, combined with efficient substrata mobilisation, probably resulted in the lowest rocks travelling farthest.

In view of the above, we envisage two possible sequences of events for the collapse. 
A. Where the rocks liquefy first and cause the collapse

1.1. Pervasive failure in substrata due to progressive deformation: rocks liquefy,

1.2. Edifice responds by failing along a slip plane and a sliding wedge forms,

1.3. Sliding wedge loads frontal anticlines and contributes to substrata mobilisation,

1.4. Substrata are ejected from under wedge, carrying away some wedge material from the lower toreva blocks.

B. Where liquefaction is a consequence of a developing collapse

2.1. A sliding wedge forms within the edifice, due to loading and flexural stresses (from gradual substrata extrusion),

2.2. Wedge slips and loads frontal anticlines,

2.3. Anticlines fail, substrata are liquefied by sudden shear stress increase,

2.4. Substrata are ejected from under wedge, carrying some wedge material with them.

\section{Integrated collapse model}

Socompa was built up on the edge of a thrust sequence generated by spreading of the older Pajonales Volcano. It grew rapidly after the last glaciation and consequent gravitational deformation developed a series of thrust anticlines below its northwest and northern flanks, which interfered with those of Pajonales. The anticlines incorporated volcanoclastic deposits from the volcano, indicating that anticline development was concurrent with volcano growth. The nearest anticlinal ridge to the volcano, Loma Alta was diverting drainage and lava flows northeastwards and southwestwards (Fig. 14). Prior to collapse, the summit of Socompa was about $3000 \mathrm{~m}$ above its base and the anticlinal hills were up to $300 \mathrm{~m}$ high (Figs. 13 and 14). The deformation front extended about $5 \mathrm{~km}$ from the volcano base (Figs. 13 and 14).

At the time of collapse, Socompa was actively growing, emplacing dacitic spatter-fed lava flows on its northwest flank (Fig. 13). We envisage that shear deformation was occurring as shown in Fig. 14b. The shearing was probably distributed throughout the substrata as shown in Fig. 14a, with some localisation on planes such as those shown in Fig. 14b. Pervasive shearing under the high differential stresses eventually led to a breakdown of substrata structure. The rock was 'liquefied' in a similar manner to the liquefaction of chalk and other loosely bonded porous sediments (Maltman, 1994; Petley and Allison, 1997). Failure may have been initiated by several factors, such as increased loading, progressive shear weakening, seismic forcing, or magma intrusion. Once mobilised, the substrata were ejected, dragging part of the volcano with them (Fig. $14 \mathrm{c})$. Much of this volcano material remained as toreva blocks, but about $5.5 \mathrm{~km}^{2}$ was transported on top of the avalanche forming the Monturaqui unit. Due to its highly mobilised state, substrata material was ejected at right angles to the main collapse direction to form the distinct northern El Cenizal unit. At some time during collapse, part of the Loma Alta Anticline also failed northwards in slump blocks. An eruption of pumice followed the collapse and new lavas have built a cone within the scar wedge.

\section{Conclusions}

(1) Gravitational deformation has developed at Socompa by substrata extrusion, expressed by a series of thrust anticlines.

(2) Failure of the substrata within the anticlines led to sector collapse and avalanche, dominantly composed of substrata.

(3) Progressive strain weakening, progressive rock fracturing and increased loading lead to pervasive failure in the sub-volcanic strata. The substrata fragmented and liquefied and were ejected from below the volcano.

(4) The initial mobilisation of substrata as a fine, homogenous granular material maintained a highly mobile lower avalanche layer.

(5) The ejection of mobilised substrata from under the edifice facilitated transport of avalanche material.

(6) The weak substrata layer, which is a prerequisite for deformation, can be formed of what are coherent brittle rock types under normal near-surface geological stress conditions. The high differential stresses produced by volcano loading can cause rocks such as ignimbrites to behave in a highly ductile manner. 
(7) Loading of thrust anticlines after growth can increase deformation if the load is emplaced behind such anticlines, as at Lomas Pajonales, or decrease it if emplaced directly onto them, as in the Negrillar lava field.

The Socompa collapse event is unique in its preservation, but to be of real value for understanding volcano collapse it should not be a unique event. The relationship of spreading to collapse has been described at just one other volcano so far: Mombacho, Nicaragua (van Wyk de Vries and Francis, 1997). There are many sector collapses, however, with similar morphology, which could have involved such processes. For example, Iriga (Philippines), Bandai San (Japan), Raung (Java) and Meru (Tanzania) all have wedge-shaped collapse scars. There are also many volcanoes standing on sedimentary and pyroclastic substrata that could suffer the sequence of events described here. Some of these are known to be spreading, such as Momtombo (Nicaragua) and many Javan volcanoes. Thus not only is it probable that spreading and substrata liquefaction have generated previous collapses, but there is potential for them to occur at many currently intact volcanoes. By understanding more about the mechanics of such collapses, and by careful monitoring of movement, such events are probably predictable. Certainly, potential sites can be identified by structural inspection.

\section{Acknowledgements}

Steve Foot of the Escondida Mine gave us invaluable logistic assistance, and the use of the mine's drilling camp. Jeff Witter was indispensable as a field assistant. The Monturaqui Chilean army camp, Chilean and Argentinean border guards all were very helpful. We would like to thank Geoff Wadge and Derek Rust for their thorough reviews. We are thankful for the one anonymous reviewer for his comments on the original manuscript, withdrawn from Bulletin of Volcanology because of editorial delays. The fieldwork was supported by NSF grant EAR 9116693 to P.W. Francis and S. Self. B. van Wyk de Vries was supported by a Leverhulme Trust fellowship, and an Open University research development grant.

\section{References}

Campbell, S.C., 1989. Self-lubrication for long runout landslides. J. Geol. 97, 653-665.

Cleary, P.W., Campbell, S.C., 1993. Self-lubrication for long runout landslides: examination by computer simulation. J. Geophys. Res. 98, 21911-21924.

Day, S., 1996. Hydrothermal pore fluid pressure and the stability of porous, permeable volcanoes. In: McGuire. W. J., et al. (Eds.), Geol. Soc. Spec. Publ. 110, pp. 77-94.

Deruelle, B., 1978. The Nergos de Aras nuée ardente deposits: a cataclysmic eruption of Socompa volcano (Andes of Atacama, north Chile). Bull. Volcanol. 41, 175-186.

Francis, P.W., Gardeweg, M., Ramirez, C.F., Rothery, D.A., 1985. Catastrophic debris avalanche deposit of Socompa volcano, northern Chile. Geology 13, 600-603.

Francis, P.W., Self, S., 1985. Collapsing volcanoes. Sci. Am. 255, 90-97.

Iverson, R.M., Reid, M.E., La Husen, R.G., 1997. Debris-flow mobilization from landslides. Annu. Rev. Earth Planet. Sci. $25,85-138$.

Leddra, M.J., Jones, M.E., Goldsmith, A.S., 1993. Compaction and shear deformation of a weakly-cemented, high porosity sedimetary rock. In: Crips, et al. (Eds.). The engineering geology of weak rock. Balkema, Rotterdam.

Maltman, A., 1994. The geological deformation of sediments. Chapman \& Hall, London (362pp.).

Melosh, H.J., 1979. Acoustic fluidisation; a new geologic process?. J. Geophys. Res. 84, 7513-7520.

Merle, O., Abidi, N., 1995. Approche expérimentale du fonctionnement des rampes émergents. Bull. Soc. Géol. Fr. 166, 439-450.

Merle, O., Borgia, A., 1996. Scaled experiments of volcanic spreading. J. Geophys. Res. 101, 13805-183817.

Merle, O., Vendeville, B.C., 1995. Experiemental modelling of thin-skinned shortening around magmatic intrusions. Bull. Volcanol. 57, 33-43.

Nakamura, K., 1980. Why do long rift zones develop in Hawaiian volcanoes - A possible role of thick oceanic sediments. Bull. Geo. Soc. Jpn 25, 255-267.

Petley, D.N., Allison, R.J., 1997. The mechanics of deep-seated landslides. Earth Surface Processes and Landforms 22, 747758.

Petley, D.N., Jones, M.E., Leddra, M.J., Kageson-Loe, N., 1992. On changes in fabric and pore geometry due to compaction and shear deformation of weak North Sea sedimentary rocks. In: North Sea oil and gas reservoirs, vol. III, Graham and Trotman, London.

Ramirez, C.F., 1988. The geology of Socompa volcano and its debris avalanche deposit, northern Chile. MSc dissertation, Open University, Milton Keynes, UK.

Reiche, P., 1937. The toreva-block - a distinctive landslide type. J. Geol. 45, 538-548.

Reutter, K.-J., Döbel, R., Bogdanic, T., Kley, J., 1994. Geological map of the Central Andes between $20^{\circ} \mathrm{S}$ and $26^{\circ} \mathrm{S}$. In: Reutter, K.-J., Scheuber, E., Wigge, F. (Eds.). Tectonics of the Southern Central Andes. Springer, Berlin (333pp.).

Siebert, L., 1984. Large volcanic debris avalanches: characteristics 
of source areas, deposits, and associated eruptions. J. Volcanol. Geotherm. Res. 22, 163-197.

van Bemmelen, R.W., 1970. The Geology of Indonesia. General Geology of Indonesia and Adjacent archipelagos, 2nd ed., vol. 1A, Matinus Nijhiff, The Hague, The Netherlands.

van Wyk de Vries, B., Borgia, A., 1996. The role of basement in volcano deformation. In: McGuire W.J., et al. (Eds.), Geol. Soc. Spec. Publ. 110, pp. 95-11.

van Wyk de Vries, B., Francis, P.W., 1997. Catastrophic collapse at stratovolcanoes induced by gradual volcano spreading. Nature $387,387-390$. van Wyk de Vries, B., Matela, R.J., 1998. Styles of volcano-induced deformation: numerical models of substratum flexure, spreading and extrusion. J. Volcanol. Geotherm. Res. 81, 1-18.

van Wyk de Vries, B., Self, S., Francis, P.W., 1996. Thin skinned thrusting caused by volcanism in N Chile. Tectonic Studies Group. Research in progress, Birmingham, 12-16th December. van Wyk de Vries, B., Kerle, N., Petley, D., 2000. A sector-collapse forming at Casita volcano. Geology 28, 167-170.

Wadge, G., Francis, P.W., Ramirez, C.F., 1995. The Socompa collapse and avalanche event. J. Volcanol. Geotherm. Res. 66, 309-336. 